University of Arkansas, Fayetteville

From the SelectedWorks of Ann Killenbeck

2009

\title{
Bakke, With Teeth?: The Implications of Grutter v. Bollinger in an Outcomes-Based World
}

Ann M. Killenbeck, University of Arkansas, Fayetteville 


\title{
BAKKE, WITH TEETH?: THE IMPLICATIONS OF GRUTTER V. BOLLINGER IN AN OUTCOMES-BASED WORLD
}

\author{
ANN MALLATT KILLENBECK*
}

I. The Diversity Rationale: From InTUITION to FaCt .9

A. The Early Evolution of Affirmative Action and The Diversity Rationale 10

B. The Embrace of Intuition-Based Analysis in Bakke..................15

C. Post-Bakke Reaction .............................................................17

D. Diversity at the University of Michigan Pre-Grutter and Gratz. .20

E. The Shift to Fact-Based Analysis in Grutter and Gratz ...........22

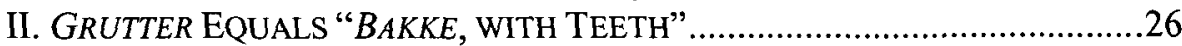

A. The Benefits of Diversity "Are Real"'......................................28

B. Grutter Allows Judicial Deference Only to an Institution's Chosen Mission

III. INSTITUTIONAL PROGRAMMING AND ASSESSMENT FOR INSTITUTIONS UTILIZING RACE-CONSCIOUS ADMISSIONS POLICIES.

A. Legal Education and Diversity: The Post-Grutter Realities .......39

B. Institutional and Programmatic Considerations in Planning for a Diverse Learning Environment ..........................................43

C. Assessment and the True Commitment to Diversity ..................53

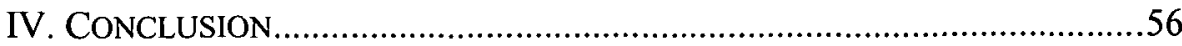

* Professor Killenbeck is an Assistant Professor at University of Arkansas School of Law. Professor Killenbeck holds both a B.A. and an M.A. in English from the University of Nebraska. She earned her J.D. from the University of Nebraska and her Ph.D. in higher education, with an emphasis on law and public policy, from the University of Michigan. Professor Killenbeck wishes to acknowledge and thank the Journal's anonymous reviewer for comments that strengthened the initial draft of this article. Professors Larry Alexander, Bryan Fair, and Goodwin Liu also reviewed the manuscript and offered criticisms that have been taken into account and improved the final product. In addition, a number of individuals at the University of Arkansas helped along the way, including Dean Cynthia Nance (both comments and summer research support) and Professors Don Judges, Mark Killenbeck, Rob Leflar, and Steve Sheppard. Finally, this Article is dedicated to the person who makes everything worthwhile, our daughter, Jessica Ann Marie. 


\section{INTRODUCTION}

On June 23, 2003, the Supreme Court handed down two rulings exploring whether group identity can be taken into account in college and university admissions policies. In the first ruling, Grutter v. Bollinger, ${ }^{1}$ a narrow five to four majority held that the University of Michigan Law School had "a compelling interest in attaining a diverse student body" and found that the policy at issue was narrowly tailored and, therefore, constitutional. ${ }^{3}$ In the second ruling, Gratz v. Bollinger ${ }^{4}$ by a somewhat larger margin of six to three, the Court acknowledged that the Grutter principle controlled. ${ }^{5}$ However, the Court held that a different admissions system employed by the University's College of Literature, Science, and the Arts was not narrowly tailored and, therefore, unconstitutional. ${ }^{6}$

The decisions were both celebrated and condemned. Michigan's President, Mary Sue Coleman, declared that the Court had handed the University and "all of higher education" a "tremendous victory," a ruling "in support of affirmative action [that] will go down in history as among the great landmark decisions of the Supreme Court." The New York Times agreed, stating that the Court had taken "a historic stand for equality of opportunity." 8 Affirmative action's opponents felt differently. Terry Pell, President of the Center for Individual Rights, the organization that brought the suits, characterized the results as "mixed decision[s]" marking "the beginning of the end of race preferences," maintaining that their "complexity ... make it risky for most schools to rely [on] these means." The Washington Times mourned "a large step backward from the goal of a colorblind society," 10 and the Wall Street Journal observed that "[a]nyone

1. 539 U.S. 306 (2003).

2. Id. at 328 .

3. Id. at $333-43$.

4. 539 U.S. 244 (2003).

5. Gratz, 539 U.S. at 268 ("For the reasons set forth today in Grutter . . . the Court has rejected" the argument that diversity is not a compelling interest).

6. See id. at 270 ("We find that the University's policy . . . is not narrowly tailored to achieve the interest in educational diversity that [the University claims] justifies [its] program.”).

7. Press Release, University of Michigan, U.S. Supreme Court rules on University of Michigan Cases (June 23, 2003), available at http://umich.edu/news/index.html?Releases/2003/Jun03/supremecourt2.

8. Editorial, $A$ Win for Affirmative Action, N.Y. TIMES, June 24, 2003, at A30 [hereinafter N.Y. TIMES Editorial].

9. Press Release, The Center for Individual Rights, Supreme Court's mixed decision on race preferences (June 23, 2003), available at http://www.cirusa.org/releases/63.html [hereinafter CIR Press Release].

10. Editorial, Bad Law on Preferences, WASH. TIMES, June 25, 2003, at Al6. 
looking for legal, much less moral, clarity ... was surely disappointed."11

Six years later the meaning of these decisions and the requirements they impose on institutions wishing to pursue racial diversity are still at issue. ${ }^{12}$ In August, 2008, for example, the Office for Civil Rights (OCR) in the United States Department of Education issued a "Dear Colleague" letter in response to what it characterized as "numerous inquiries from postsecondary institutions, individuals and private organizations, about the impact" of the two decisions. ${ }^{13}$ Stressing the "highly suspect nature" of "racial classifications," the letter described the "parameters" within which OCR would assess affirmative admissions policies. ${ }^{14}$ Roger Clegg, President and General Counsel of the Center for Equal Opportunity, characterized the statement as a "belated" but "helpful and legally sound description of what the Supreme Court held [in the Gratz and Grutter decisions]."15 The National Association for the Advancement of Colored People ("NAACP") Legal Defense Fund, on the other hand, condemned the letter as an attempt on the part of OCR "to further its efforts to subvert and give unnecessary pause to higher education institutions that are pursuing a racially diverse student population in a constitutional manner."16

None of this is unexpected. Affirmative action has always been and likely will always remain a highly divisive issue, especially when examined under the arguably artificial light cast by litigation and political discourse. Professor Jack Greenberg was an Assistant Counsel for the NAACP Legal Defense and Educational Fund and litigated many of the most important civil rights cases decided between 1949 and 1984 . He has noted that "[o]pposing sides in the war over affirmative action in higher education have generated a rat's nest of arguments over facts, philosophy, and constitutional law."17

11. Editorial, Supreme Court Quotas, WALl ST. J., June 24, 2003, at A16 [hereinafter WALL ST. J. Editorial].

12. Grutter and Gratz both focused expressly and exclusively on racial diversity. That was not surprising, since the Court itself framed the question presented in those terms. See infra text accompanying note 140 . Diversity properly understood is, however, about much more than that. See infra text accompanying note 42 .

13. Letter from Stephanie J. Monroe, Assistant Secretary for Civil Rights (Aug. 28, 2008), available

http://www.ed.gov/about/offices/list/ocr/letters/raceadmissionpse.html

14. Id.

15. Scott Jaschik, Guidance or Spin on Affirmative Action?, INSIDE HIGHER EDUC., Sept. 19, 2008, available at http://www.insidehighered.com/news/2008/09/19/ocr.

16. Statement of the NAACP Legal Defense Fund on Diversity in Higher Education (Sept. 19 , http://www.naacpldf.org/content.aspx?article=1323.

17. Jack Greenberg, Diversity, the University, and the World Outside, 103 COLUM. L. REV. 1610, 1610 (2003). For a sampling of the literally hundreds of articles, pro and con, see the following symposia: Post-Grutter: What Does Diversity Mean in Legal Education and Beyond?, 35 PEPP. L. REv. 569-732 (2008); Meeting the Challenge of 
Even the most cursory examination of the literature bears this out. For example, in the wake of the first higher education affirmative action case to reach the Court, Regents of the University of California v. Bakke, ${ }^{18}$ Professor Derrick Bell described the sorts of programs countenanced by that decision as "modest mechanism[s] for increasing the number of minority professionals, adopted as much to further the self-interest of the white majority as to aid the designated beneficiaries." 19 Then-Professor Richard Posner disagreed, characterizing group preference admissions policies as an "administrative convenience" and "a source of both economic injury and profound personal resentment to members of the excluded racial or ethnic groups...."20 Similar disputes arose after Grutter and Gratz were decided. A "Joint Statement" signed by some of the nation's most prominent constitutional law scholars argued that the decisions "have affirmed the underlying values of diversity in higher education and of racial integration in American society [and] provide clear guidelines for institutions to use in designing inclusive admissions policies."21 But Professors Larry Alexander and Maimon Schwarzschild characterized them as "dubious as constitutional law" and argued that there is "overwhelming reason" to the effect that "preferential affirmative action is [not] a good thing."22

What is surprising is the extent to which even those who favor affirmative action argue between and among themselves about the meaning of Grutter and Gratz and what those decisions require. For example, having carried the day before the Court, many of affirmative action's champions now question both the propriety of the diversity rationale and the costs that the pursuit of diversity impose. Professor Bell, for example, argues that "the concept of diversity, far from a viable means of ensuring

Grutter-Affirmative Action in Twenty-Five Years, 67 OHо ST. L.J. 1-345 (2006); From Brown to Bakke to Grutter: Constitutionalizing and Defending Racial Equality, 21 CONST. COMMENT. 1-250 (2004); From Brown to Grutter: Affirmative Action and Higher Education in the South, 78 TUL. L. REV. 1765-2278 (2004); On Grutter and Gratz: Examining Diversity in Education, 103 COLUM. L. REV. 1589-1639 (2003); Affirmative Action: Diversity of Opinions, 68 U. COLO. L. REV. 833-1229 (1997); Regents of the University of California v. Bakke, 67 CAL. L. REV. 1-255 (1979).

18. 438 U.S. 265 (1978).

19. Derrick A. Bell, Jr., Bakke, Minority Admissions, and the Usual Price of Racial Remedies, 67 CAL. L. ReV. 3, 17 (1979).

20. Richard A. Posner, The Bakke Case and the Future of "Affirmative Action," 67 CAL. L. REV. 171, 177 (1979).

21. A JoInt Statement of Constitutional Law Scholars, Reaffirming DIVERSITY: A LEGAL ANALYSIS OF THE UNIVERSITY OF MiCHIGAN AFFIRMATIVE ACTION CASES 26 (July 2003) [hereinafter JOINT STATEMENT]. The statement was signed by Professors Erwin Chemerinsky, Drew Days III, Richard Fallon, Pamela S. Karlan, Kenneth L. Karst, Frank Michelman, Eric Schnapper, Laurence H. Tribe, and Mark Tushnet.

22. Larry Alexander and Maimon Schwarzschild, Grutter or Otherwise: Racial Preferences and Higher Education, 21 CONST. COMMENT. 3, 3 (2004). 
affirmative action in the admissions policies of colleges and graduate schools, is a serious distraction in the ongoing efforts to achieve racial justice."23 Professor D. Marvin Jones in turn maintains that "Grutter is a very conservative framework at war with the project of affirmative action" and that it "is not a victory, but a defeat in disguise." 24 More tellingly, even those who agree with the holding in Grutter dispute the extent to which institutions adopting affirmative admissions policies need to pursue anything more than structural diversity, that is, simply identifying and matriculating a diverse class. Professor Dorothy A. Brown argues that "[s]tructural diversity without more... will not" achieve the goals embraced by the Court in Grutter because it "will not influence student outcomes." 25 Dean Evan Caminker of the Michigan Law School disagrees, maintaining that "neither the majority nor concurring opinions ever suggested... that any post-admission programming efforts were a precondition for the validity of admissions-related diversity efforts." 26

My focus in this article is on key aspects of these debates. One common post-Grutter theme is that the decision simply provided the "fifth vote,",27 that is, that it gave binding constitutional force to Justice Powell's acceptance of diversity as a compelling educational interest in Bakke. I disagree. Rather, I argue that by clearly embracing the arguments that Michigan made at trial and on appeal, Grutter went further than Justice Powell did in Bakke and imposes stringent requirements on institutions using race as a factor in admissions decisions.

Michigan's litigation strategy was intentional and well-crafted. The president of the University when the litigation began, Lee $\mathrm{C}$. Bollinger, understood that "Justice Powell's decisive opinion in Bakke... specifically precluded any justification of using race and ethnicity as factors in admissions as a 'remedy' for past societal discrimination."28

23. Derrick Bell, Diversity's Distractions, 103 CoLUM. L. REV. 1622, 1622 (2003).

24. D. Marvin Jones, Plessy's Ghost: Grutter, Seattle, and the Quiet Reversal of Brown, 35 PEPP. L. Rev. 583, 585 (2008).

25. Dorothy A. Brown, Taking Grutter Seriously: Getting Beyond the Numbers, 43 Hous. L. REV. 1, 17 (2006).

26. Evan Caminker, Post-Admissions Educational Programming in a Post-Grutter World: A Response to Professor Brown, 43 Hous. L. REv. 37, 40 (2006).

27. See, e.g., WaLl ST. J. Editorial, supra note 11, at A16 (O'Connor's opinion "has given [the Powell] view the fifth vote it needed to become the law of the land"); N.Y. TIMES Editorial, supra note 8, at A30 ("the court reaffirmed Bakke and proceeded to use it as a template").

28. Lee C. Bollinger, A Comment on Grutter and Gratz v. Bollinger, 103 Colum. L. REV. 1589, 1590 (2003). The University studiously avoided embracing the only other constitutionally acceptable justification for employing race-based admissions criteria, the "compelling interest of remedying the effects of [its own] past intentional discrimination." Parents Involved in Cmty. Sch. v. Seattle Sch. Dist. No. 1, 551 U.S. 701,720 (2007). As a number of civil rights advocates recognized, resorting to that 
Michigan decided accordingly to argue that what was characterized simply as a "belief' in Justice Powell's opinion in Bakke was demonstrable fact: that the "atmosphere of 'speculation, experiment and creation'-so essential to the quality of higher education-is ... promoted by a diverse student body." 29 In particular, Michigan and its amici developed and relied on "extensive evidence" that "a racially diverse student body" results in specific, tangible outcomes. ${ }^{30}$

Justice O'Connor's opinion for the Court in Grutter emphasized and embraced the key element in Michigan's litigation strategy: its contention that the educational benefits are "substantial" and that they "are not theoretical but real...."31 This is powerful language by the Court, phrasing that strongly suggests that it actually expects these outcomes to result from a racially diverse educational environment.

The good news for higher education is that Justice O'Connor and her colleagues were persuaded that the pursuit of diversity is constitutional. The potentially bad news is that there is every reason to believe that institutions that employ race conscious admissions policies will be held to the standards for which they argued. Namely, that they will need to show that positive educational outcomes are occurring due to the resulting matriculation of a diverse student population. I believe that this is the logical consequence of what narrow tailoring means in a post-Grutter world, ${ }^{32}$ one within which institutions must be ever mindful that a general rule that race might be considered in admissions decisions does not insulate particular programs from legal challenges.

approach "would not only be embarrassing for the university; it also might open the school to lawsuits by black and Latino students who faced discrimination." GREG Stohr, A Black and White Case: How Affirmative Action Survived Its Greatest Legal Challenge 83 (2004) (noting the concerns of Theodore M. Shaw, the Director-Counsel and President of the NAACP Legal Defense and Educational Fund at the time, in a chapter discussing the "Arguments Michigan Wouldn't Make"). Two groups were eventually allowed to intervene in the case to press those claims. The District Court refused their request; see Gratz v. Bollinger, 183 F.R.D. 209 (E.D. Mich. 1998), but the Court of Appeals reversed, "find[ing] persuasive their argument that the University is unlikely to present evidence of past discrimination by the University itself or of the disparate impact of some current admissions criteria . . . "Grutter v. Bollinger, 188 F.3d 394, 401 (6th Cir. 1999).

29. Bakke, 438 U.S. at 312 (opinion of Powell, J.) (quoting Sweezy v. New Hampshire, 354 U.S. 234, 263 (1957) (Frankfurter, J., concurring)).

30. See, e.g., Brief for Respondents at 21-26, Grutter v. Bollinger, 539 U.S. 306 (2003) (No. 02-241). A number of the amicus briefs were devoted almost exclusively to the social science evidence. See, e.g., Brief for the American Sociological Association et al. as Amici Curiae Supporting Respondents, Grutter v. Bollinger, 539 U.S. 306 (2003) (No. 02-241); Brief for the American Educational Research Association et al. as Amici Curiae Supporting Respondents, Grutter v. Bollinger, 539 U.S. 306 (2003) (No. 02-241).

31. Grutter v. Bollinger, 539 U.S. 306, 330 (2003).

32. See infra text accompanying note 181 . 
This is clearly not bad in an absolute sense, since institutions that voluntarily embrace race-sensitive admissions policies presumably do so for the right reasons. That is, they do so because of the educational benefits associated with diversity, spelled out in light of the institution's particular mission. Unfortunately, that is not always the case. The need to do so nevertheless reflects both the opportunities and the challenges higher education now faces, given the reality of what the Court actually did in Grutter. My point in this article is not that the current legitimacy of diversity as a compelling interest is in doubt, or that institutions will be required to repeatedly defend and prove that point. It is rather that the reality of the actual results that follow from diversity plays a very important role in defending the constitutionality of individual diversity policies. ${ }^{33}$

It is in this respect that I argue in this article that Grutter is in effect Bakke with teeth: a holding that allows colleges and universities to use race-based affirmative action in pursuit of diversity, but also imposes new obligations on the institutions that do so. The Court accepted the contention that diversity is a compelling educational interest. But it did so in a context that made it quite clear that a major consideration was the expectation that the positive educational outcomes associated with diversity actually occur, and not on the intuitive belief that such outcomes were simply possibilities that might follow from the matriculation of a diverse entering class.

My argument in this article proceeds in four steps. In Part I, I briefly outline the origins and development of what is now known as the diversity rationale. In particular, I note the seeds of that argument in Sweatt v. Painter, ${ }^{34}$ its nominal adoption by Justice Powell in Regents of the University of California v. Bakke, ${ }^{35}$ and its refinement and formal acceptance by the Court in Justice O'Connor's opinion in Grutter.

In Part II, I argue that the Grutter Court's embrace of diversity is far more rigorous than many scholars have to date contended. Specifically, I maintain that Grutter is in effect "Bakke with teeth" because the paradigm adopted by the Court stresses that diversity constitutes a compelling interest precisely because the educational benefits flowing from a racially diverse environment are "not theoretical but real." deferring to institutions concerning their admissions policies, the Court simply acknowledged their right to adopt their own institutional missions. That is, each institution has the right to adopt a mission that embraces diversity as an integral element of the educational objectives that it wishes

33. See infra text accompanying notes $361-365$.

34. 339 U.S. 629 (1950).

35. 438 U.S. 265 (1978).

36. Grutter, 539 U.S. at 330. 
to pursue. But the proper use of otherwise constitutionally suspect admissions criteria-in this instance race or ethnicity-will succeed when challenged only if an institution can show two things; that the use of such criteria follow from and reflect its mission, and that the benefits associated with diversifying its student body are actually occurring.

In Part III, I discuss specific consequences that follow from these realities, using the situation that law schools now find themselves in to illustrate both the obligations and opportunities that arise as a result of Grutter. That focus reflects more than the simple fact that the dispute in Grutter was about the consideration of race in the admissions decisions at the University of Michigan Law School. Legal education is, I believe, an especially apt vehicle for examining the realities that follow in the wake of Grutter and Gratz. Law schools are, by their very nature, selective institutions within which the need to use constitutionally questionable criteria in the admissions process is especially pronounced. ${ }^{37}$ Moreover, in direct response to Grutter, the accrediting agency for law schools, the American Bar Association, made the pursuit of diversity a mandate rather than a choice, ${ }^{38}$ a development that is important in and of itself and that assumes even greater significance given that the ABA is now also in the process of moving from an "input" to an "outcomes" model for law school accreditation. ${ }^{39}$

In Part III-B, I highlight the importance of certain key social science evidence that bears on these matters. In particular, I note that the clear consensus within the expert community that structural, or numeric, diversity is necessary, but not sufficient, to produce the educational, social and democracy outcomes noted in Grutter. My central premise is then that Grutter and Gratz require more of institutions that choose to use race as a factor in their admissions decisions than the structural diversity that, for example, Dean Caminker characterized as sufficient to meet the rigors of strict scrutiny. ${ }^{40}$ In Part III-C, I discuss the need for and importance of a commitment to continuous and rigorous assessment of institutional

37. See infra text accompanying notes 236-244.

38. AMERICAN BAR ASSOCIATION, 2008-09 STANDARDS FOR APPROVAL OF LAW SCHOOLS, CHAPTER 2: ORGANIZATION AND ADMINISTRATION, Standard 212(a) (stating that all law schools "shall demonstrate by concrete action a commitment to providing full opportunities for the study of law and entry into the profession by members of underrepresented groups, particularly racial and ethnic minorities, and a commitment to having a student body that is diverse with respect to gender, race, and ethnicity."), available at http://www.abanet.org/legaled/standards/standards.html (emphasis added). I discuss the details and implications of this infra at text accompanying notes 258-270.

39. AMERICAN BAR ASSOCIATION, SECTION OF LEGAL EDUCATION AND ADMISSIONS TO THE BAR, REPORT OF THE OUTCOME MEASURES COMMITTEE 1 (July 27, 2008) ("T[his] report recommends that the Section re-examine the current ABA Accreditation Standards and reframe them, as needed, to reduce their reliance on input measures and instead adopt a greater and more overt reliance on outcome measures.").

40. See infra text accompanying notes $272-336$. 
diversity efforts.

Grutter and Gratz provide higher education institutions with both an opportunity and a challenge. The opportunity is to remove at least some of the ties that bind public opinion about affirmative action programs. Institutions that fashion creative, proactive programs will be in a position to show that the benefits that can result from a diverse educational environment are in fact occurring. Public support for race-conscious admissions programs in higher education is lacking. ${ }^{41}$ Institutions of higher education, and law schools in particular, that begin serious and transparent outcomes assessment programs will free the public, and the students at these institutions, to fully embrace the laudable goals of diversity. The challenge is to recognize the need for such actions and to undertake them for both the right reasons and in the right way.

A second challenge is to find the will to eventually shift perspectives and realize that true diversity involves much more than the color of one's skin. My focus in this Article is on racial diversity and the requirements the Court has now imposed on institutions that pursue that goal. That emphasis is both necessary and unfortunate. It is necessary because current discussions of diversity inevitably hone in on two and only two characteristics: race and/or ethnicity. Properly understood, however, diversity is about much more. It involves the full range of characteristics and perspectives associated with personal identity. These traits include, but reach far beyond, the color of one's skin. They involve a wide range of beliefs, assumptions, and quite possibly prejudices: the individual views and values that make each of us distinct. Programs and policies that reduce us to a single denominator are accordingly unfortunate. I am confident that the higher education establishment would argue in response that true diversity is what they seek. The reality is that most policies and procedures inevitably focus on a single consideration, race, and that the litigation, political movements, and accreditation standards that follow in their wake track this emphasis. ${ }^{42}$

\section{The Diversity RATIONALE: From InTUITION TO FaCT}

One common reaction to Grutter and Gratz was the belief that the Court simply cleared up the confusion sown by the fact that the Bakke Court was deeply divided, with no clear majority opinion. ${ }^{43}$ In Bakke's wake a widely

41. See infra text accompanying notes $347-356$.

42. I thank Professor Larry Alexander for reminding me of this. I also note that one reason why this has happened is the reality that the Supreme Court has consistently stressed that race is the one characteristic that should virtually never matter. That makes its use both controversial and, in the light of the rigors of strict scrutiny, an inviting litigation target.

43. See supra note 27 and accompanying text. 
shared assumption was that Justice Powell spoke for the Court. ${ }^{44}$ This belief, however, was not universal. ${ }^{45}$ Recognizing this, affirmative action's opponents crafted a concerted litigation strategy that "us[ed] techniques first honed by leaders of the civil rights movement," 46 albeit with the avowed objective of either establishing that the Powell opinion did not control or, in the alternative, providing the Court with the opportunity to hold expressly that affirmative admissions policies were unconstitutional. ${ }^{47}$ These efforts eventually brought the Michigan plans before the Court.

Justice O'Connor did declare in Grutter that the Court "endorse[s] Justice Powell's view that student body diversity is a compelling interest that can justify the use of race in university admissions." ${ }^{\prime 4}$ But the Court did more than simply provide Justice Powell with a belated fifth vote or use his opinion as a template. Rather, it employed an analytic matrix within which what had been an extremely deferential view of the permissibility of affirmative action was transformed into what $I$ argue is now a rigorous constitutional standard. Before seeing why this is the case, however, it is important to briefly review the history of higher education diversity in this country so that the Grutter decision can be placed in context.

\section{A. The Early Evolution of Affirmative Action and The Diversity Rationale}

The quest to give effect to the constitutional guarantee that all individuals are entitled to the equal protection of the laws was initially understood to mean that race simply should not matter. One of the most eloquent statements of this principle was made by Professor Alexander Bickel, who characterized the legal regime in the wake of Brown v. Board of Education 49 as one within which "[t]he lesson of the great decisions of the Supreme Court and the lesson of contemporary history have been the

44. See, e.g., Antonin Scalia, The Disease as Cure, 1979 WASH. U. L.Q. 147, 148 (characterizing Justice Powell's opinion as "the law of the land").

45. See, e.g., Charles Fried, The Supreme Court, 1994 Term-Foreword: Revolutions?, 109 HARV. L. REV. 13, 47 (1995) ("What is called the controlling opinion in Bakke, authored by Justice Powell, was in fact joined by no other member of the Court."). Fried concedes the "influence" of the Powell opinion, but stresses that "the resolution was an equivocal one." Id. That reality opened the door to what followed. See, e.g., Hopwood v. Texas, 78 F.3d 932, 944 (5th Cir. 1996) ("Justice Powell's view in Bakke is not binding precedent on this issue").

46. David Segal, Putting Affirmative Action on Trial, WASH. POST, Feb. 20, 1998, at A1. The firm was the Center for Individual Rights, which brought both the challenge to affirmative action litigated in the Hopwood case, see supra text accompanying note 45, and the two Michigan cases, Grutter, 539 U.S. 306 (2007) and Gratz, 539 U.S. 244 (2007).

47. Id. at A16 (noting that "[a]t CIR, the quarry is University of California Regents v. Bakke").

48. Grutter, 539 U.S. at 325.

49. 347 U.S. 483 (1954). 
same for at least a generation: discrimination on the basis of race is illegal, immoral, unconstitutional, inherently wrong, and destructive of democratic society." 50 That statement accurately captured what had been the central theme in the movement that fought to make the constitutional promise of equality a legal, political, and social reality: the assumption that, in the normal course of events, an individual's race should not be taken into account when government acts. ${ }^{51}$ Rather, decisions should be made on the basis of individual talents and qualifications, and not group identity. As the Court declared in one of the first cases to analyze the Equal Protection Clause: "What is this but declaring that the law shall be the same for the black as for the white; that all persons, whether colored or white, shall stand equal before the laws ... ?"52 Eighty-plus years later, Dr. Martin Luther King, Jr. made what was in effect the same observation, stating famously that the civil rights movement was a quest for "a nation where [people] will not be judged by the color of their skin but by the content of their character." 53

The original arguments in favor of affirmative action reflected that goal. The objective was a system that operated in a fair and open way. The "overarching policy" was "neutrality." 54 The obligation that followed from this was in turn to create nondiscriminatory policies and practices within which "decisions are made on merit, with neither positive nor negative reference to minority determinative characteristics." 55 The assumption was that everything would be fair and open, which "[p]resumably ... meant such things as advertising the fact [that openings exist], seeking out qualified applicants from sources where they might be found, and the like." 56 Such policies were affirmative in the sense that steps would be

50. AleXANDER M. BICKEL, THE MORALITY OF CONSENT 133 (1975).

51. The stress here on government decisions reflects the fact that the Equal Protection Clause applies only where government acts. The Court made it clear in both Grutter and Bakke, however, that the same analysis and principles apply when parsing Title VI of the Civil Rights Act of 1964, which does bind private institutions. See Grutter, 539 U.S. at 343 ("Consequently, petitioner's statutory claims based on Title VI . . . also fail."); Regents of the Univ. of Cal. v. Bakke, 438 U.S. 265, 287 (1978) (opinion of Powell, J.) ("Title VI must be held to proscribe only those racial classifications that would violate the Equal Protection Clause of the Fifth Amendment.") (quoting General Building Contractors Ass'n., Inc. v. Pennsylvania, 458 U.S. 375, 389-91 (1982)).

52. Strauder v. West Virginia, 100 U.S. 303, 307 (1879).

53. Martin Luther King, Jr., I Have A Dream, in A Testament OF Hope: THE ESSENTIAL WRITINGS AND SPEECHES OF MARTIN LUTHER KING, JR. at 217, 219 (James Melvin Washington ed., 1986).

54. Developments in the Law, Employment Discrimination and Title VII of the Civil Rights Act of 1964, 84 HARV. L. REV. 1109, 1300 (1971).

55. Id. at $1300-01$.

56. Nathan Glazer, AfFirmative Discrimination: ETHNic INEQuality and Public Policy 46 (1975). 
taken to eliminate bias and see that all qualified candidates could compete on a level playing field.

The dilemma for higher education was what to do when "the use of certain standards"-for example, applying the same admissions requirements to all applicants- "result[s] in the exclusion of women and minorities from ... or their inclusion only in token proportions to their availability.....57 Critics maintained that persistent poverty and social disadvantage meant that the playing field could never be level ${ }^{58}$ and that decades of discrimination made it necessary to seek both equal treatment and equal achievement. ${ }^{59}$ The goal became "not just equality as a right and a theory but equality as a fact and equality as a result." ${ }^{.60}$ The emphasis shifted and the central assumption became, as Justice Blackmun noted in Bakke, that "[i]n order to get beyond racism, we must first take account of race." ${ }^{61}$

Early decisions of the Court hinted at what would come. In Sweatt $v$. Painter, ${ }^{62}$ for example, the question was whether the state of Texas could

57. American Association of University Professors, Affirmative Action in Higher Education: A Report by the Council Committee of Discrimination, in AAUP POLICY DOCUMENTS AND REPORTS 155, 155 (1995) [hereinafter AAUP REPORT]. The report was approved by the Association's Council in April 1973.

58. See, e.g., Derrick Bell, Xerces and the Affirmative Action Mystique, 57 GEO. WASH. L. REV. 1595, 1605 (1989) (discussing the impact of "class disadvantage" and arguing that "the qualifications they insist on are precisely the credentials and skills that have long been denied to people of color"). See also HIGHER EDUCATION FOR DEMOCRACY: A REPORT OF THE PRESIDENT'S COMMISSION ON HIGHER EDUCATION, cited in 2 AMERICAN HIGHER EDUCATION: A DOCUMENTARY HISTORY 970, 977 (Richard Hofstadter \& Wilson Smith eds., 1961) ("The old, comfortable idea that 'any boy' can get a college education who has it in him simply is not true.").

59. See, e.g., Harry T. Edwards \& Barry L. Zaretsky, Preferential Remedies for Employment Discrimination, 74. MICH. L. REV. 1, 2 (1975) ("The most effective form of affirmative action is temporary preferential treatment."); Graham Hughes, Reparations for Blacks, 43 N.Y.U. L. REV. 1063, 1071 (1968) ("it will probably also be necessary in the short run to institute a policy of discrimination in reverse in favor of disadvantaged groups").

60. Lyndon B. Johnson, To Fulfill These Rights, Commencement Address at Howard University (June 4, 1965), in 2 PUBLIC PAPERS OF THE PRESIDENTS OF THE UNITED STATES, 1965, 635, 636 (1966).

61. Regents of the Univ, of Cal. v. Bakke, 438 U.S. 265, 407 (1978) (opinion of Blackmun, J.).

62. 339 U.S. 629 (1950). The Court first addressed discrimination in legal education in Missouri ex rel. Gaines v. Canada, 305 U.S. 337 (1938), in which it held that the state of Missouri's failure to provide any legal education for African Americans within the state itself violated the equal protection guarantee. The Court made it clear, however, that the decision did not rest on the quality or nature of the education that Missouri's African-Americans could receive in another state. $I d$. at 349 ("The basic consideration is . . . what opportunities Missouri itself furnishes to white students and denies to negroes solely upon the ground of color."). While important then, the case does not overtly embrace what we now recognize as the diversity rationale. 
establish a separate program of legal education for its African American residents at Texas State University for Negroes. ${ }^{63}$ The University of Texas Law School had refused to admit Heman Sweatt "solely because he is a Negro" 64 and argued that it could fulfill whatever legal obligations it had by creating a separate program. The Court rejected that approach. It stressed that legal education was a complex and interactive process that required very specific types of resources. ${ }^{65}$ It noted that the University of Texas Law School was a nationally recognized and unique educational, political, and social resource. ${ }^{66}$ And it stressed that no other program in the state could possibly be considered the "equal" of the one at the University of Texas, especially one created at the last minute and lacking virtually all of the characteristics that made the University program nationally visible. ${ }^{67}$

The Court's ruling used language that reflected the values of what is now known as "diversity." It emphasized the interactive nature of legal education and the vital role that access to a variety of perspectives played in the learning process:

The law school, the proving ground for legal learning and practice, cannot be effective in isolation from the individuals and institutions with which the law interacts. Few students and no one who has practiced law would choose to study in an academic vacuum, removed from the interplay of ideas and the exchange of views with which the law is concerned. The law school to which Texas is willing to admit petitioner excludes from its student body members of the racial groups which number $85 \%$ of the population of the State and include most of the lawyers, witnesses, jurors, judges, and other officials with whom petitioner will inevitably be dealing when he becomes a member of the Texas bar. With such a substantial and significant segment of society excluded, we cannot conclude that the education offered petitioner is substantially equal to that which he would receive if admitted to the University of Texas Law School. ${ }^{68}$

This commitment to true equality of opportunity was strengthened in a companion case decided the same day, McLaurin v. Oklahoma State Regents for Higher Education. ${ }^{69}$ There, the Court considered whether the University of Oklahoma could meet its legal obligations when by admitting George W. McLaurin to a doctoral program in education, but requiring him

63. Sweatt, 339 U.S. at 633.

64. Id. at 631 .

65. Id at $633-34$.

66. Id. at 634 .

67. Id. at 634-35.

68. Id. at 634 .

69. 339 U.S. 637 (1950). 
to "sit apart at a designated desk in an anteroom adjoining the classroom" and to study and eat at separate tables. ${ }^{70}$ It rejected that approach, finding that the physical and social isolation of the student made it clear that his educational opportunities could not, in either theory or fact, be characterized as equal: "Such restrictions impair and inhibit his ability to study, to engage in discussions and exchange views with other students, and, in general, to learn his profession." 71 The Court also stressed the social dimensions of McLaurin's education in language that foretold Grutter, noting that

[o] ur society grows increasingly complex, and our need for trained leaders increases correspondingly. Appellant's case represents, perhaps, the epitome of that need, for he is attempting to obtain an advanced degree in education, to become, by definition, a leader and trainer of others. Those who will come under his guidance and influence must be directly affected by the education he receives. Their own education and development will necessarily suffer to the extent that his training is unequal to that of his classmates. ${ }^{72}$

These decisions did not hold that the "separate but equal" doctrine was invalid. That came a few years later, initially in Brown v. Board of Education $^{73}$ for K-12 education and then for higher education in yet another case involving legal education, Florida ex rel. Hawkins v. Board of Control of Florida. ${ }^{74}$ The Florida Supreme Court had held that "equality of treatment need not mean identity of treatment" and that the existence of a "separate but equal" black law school at Florida Agricultural and Mechanical College meant that the state did not have to admit Virgil Hawkins to the University of Florida College of Law. ${ }^{75}$ The Court, in a brief per curiam opinion, disagreed, stating that "on the authority of" Brown, Hawkins "is entitled to prompt admission under the rules and regulations applicable to other qualified candidates." 76

70. Id. at 640 .

71. Id. at 641 .

72. Id. The emphasis here is on unequal treatment, rather than diversity per se. The language nevertheless reflects one of the elements that Justice O'Connor would stress in her opinion for the Court in Grutter, that "universities, and in particular, law schools, represent the training ground for a large number of our Nation's leaders .... In order to cultivate a set of leaders with legitimacy in the eyes of the citizenry, it is necessary that the path to leadership be visibly open to talented and qualified individuals of every race and ethnicity." Grutter v. Bollinger, 539 U.S. 306, 332 (2003) (citations omitted).

73. 347 U.S. 483, 495 (1954) ("We conclude that in the field of public education the doctrine of 'separate but equal' has no place.").

74. 350 U.S. 413 (1956).

75. State ex rel. Hawkins v. Bd. of Control, 60 So. $2 d$ 162, 165 (Fla. 1952).

76. Hawkins, 350 U.S. at 414. 
The core principle in each of these cases was equal treatment. Affirmative action, at least as it was initially understood and practiced, reflected that goal. Laurence Silberman, a key figure in the early development of affirmative action policies in his capacity as Undersecretary of Labor from 1970 to 1973, summarized what was afoot when he observed that "[w]e wished to create a generalized, firm, but gentle pressure to balance the residue of discrimination." "77 Many maintained that this was not enough, with one blunt assessment arguing that "black people are disadvantaged as a group and what is therefore most necessary is that large numbers of them should be assisted along the paths of economic and educational advancement." 78 The general understanding remained, nevertheless, that affirmative action was a matter of procedure rather than substance and that, as phrased by the American Association of University Professors, the "first test of equal opportunity" was that "standards of competence and qualification," and, by implication, important decisions taking such matters into account, would be "set independently of the actual choices made."79

\section{B. The Embrace of Intuition-Based Analysis in Bakke}

The debate converged in Bakke. The University of California, Davis Medical School had adopted an admissions policy that was "designed to assure the admission of a specified number of students from certain minority groups." 80 The Court held that the program was unconstitutional. $^{81}$ It was, however, deeply divided. Four members of the Court believed that there was no need to decide the constitutional question. They argued that the "plain language" of Title VI of the Civil Rights Act of 1964 meant that "[r]ace cannot be the basis of excluding anyone from participation in a federally funded program." 82 A different group of four felt that the Davis program was appropriate as both a constitutional and statutory matter. They maintained that "[g]overnment may take race into account when it acts not to demean or insult any racial group, but to remedy disadvantages cast on minorities by past racial prejudice . . ." 83

77. Laurence H. Silberman, The Road to Racial Quotas, WALL ST. J., Aug. 11, 1977 , at 14 .

78. Hughes, supra note 59, at 1072.

79. AAUP REPORT, supra note 57, at 156.

80. Bakke, 438 U.S. at 269-70.

81. Id. at 320 ("The fatal flaw in petitioner's preferential program is its disregard of individual rights as guaranteed by the Fourteenth Amendment.").

82. Id. at 418 (Stevens, J., concurring in the judgment in part and dissenting in part). Chief Justice Burger and Justices Stewart and Rehnquist joined the Stevens opinion.

83. Id. at 325 (opinion of Brennan, White, Marshall, and Blackmun, JJ., concurring in the judgment in part and dissenting in part). 
Common ground, and the eventual result, was provided by Justice Powell. The University argued that its admissions program served four purposes: "reducing the historic deficit of traditionally disfavored minorities in medical schools and in the medical profession' $[;] \ldots$ countering the effects of societal discrimination; . . . increasing the number of physicians who will practice in communities currently underserved; and ... obtaining the educational benefits that flow from an ethnically diverse student body." 84

Justice Powell rejected the first three. ${ }^{85}$ But he accepted the fourth, finding that the University's argument that the "attainment of a diverse student body" was "a constitutionally permissible goal for an institution of higher education." 86 He stressed that "[t]he atmosphere of "speculation, experiment and creation' - so essential to the quality of higher educationis widely believed to be promoted by a diverse student body." 87 He also accepted the notion that "universities must be accorded the right to select those students who will contribute the most to the 'robust exchange of ideas," a goal "that is of paramount importance in the fulfillment of [higher education's] mission." 88

Institutions were thus free to take race into account in the admissions process, provided they did so by treating group identity simply as a "plus" in a particular applicant's file" and did not "insulate the individual from comparison with all other candidates for the available seats." 89 The lodestar for Justice Powell was the admissions policy employed by Harvard College, where "the race of an applicant may tip the balance in his favor just as geographic origin or a life spent on a farm may tip the balance in other candidates' cases." 90 A university or college needed to act with care. It could not, for example, set aside a set number of spaces for minority applicants, ${ }^{91}$ have different admissions standards for different groups, ${ }^{92}$ or have a two track admissions process, one for minority applicants and a different one for others. ${ }^{93}$

84. Id. at 306 (opinion of Powell, J.) (quoting Brief for Petitioner at 32).

85. Id. at $307-11$.

86. Regents of the Univ. of Cal. v. Bakke, 438 U.S. 265, 311-12 (1978).

87. Id. at 312 (quoting Sweezy v. New Hampshire, 354 U.S. 234, 263 (1957) (Frankfurter, J., concurring)).

88. Id. at 313 (opinion of Powell, J.).

89. Id. at 317 .

90. Id. at 323 (quoting Harvard College Admissions Program).

91. See id. at 279 ("16 places in the class of 100 were reserved for" minority applicants).

92. Regents of the Univ. of Cal. v. Bakke, 438 U.S. 265, 278 n.7 (1978) (minority applicants "admitted under the special program ... had benchmark scores significantly lower than many students . . . rejected under the general admissions program"); $i d$. at 279 ("minority applicants in the special program were rated only against one another").

93. Id. at 274 ("The special admissions program operated with a separate 
The analytic bottom line was that Justice Powell took the claims made by the higher education establishment at face value: educators believed that diversity enhanced the college and university experience. That intuitive judgment and the "widely" shared "beliefs" were not documented in any meaningful fashion. Rather, Justice Powell relied simply on "tradition and experience," 94 which "lend support to the view that the contribution of diversity is substantial.",95

\section{Post-Bakke Reaction}

The Bakke Court was deeply divided, but the general consensus in the wake of that decision was that Justice Powell's opinion controlled. In an article written before he joined the Court, then-Professor Antonin Scalia characterized the Powell opinion as an "excellent compromise," one that "we must work with as the law of the land."96 In her concurring opinion in Wygant v. Jackson Board of Education, ${ }^{97}$ Justice O'Connor observed that "although its precise contours are uncertain, a state interest in the promotion of racial diversity has been found sufficiently 'compelling, at least in the context of higher education, to support the use of racial considerations in furthering that interest." 98 Those statements captured what most observers believed the law to be in the wake of Bakke: diversity was a compelling educational interest, and race could be used as a factor in admissions, provided the policy in question could withstand the rigors of strict scrutiny. Indeed, as Justice O'Connor observed in Wygant, "[i]t appears, then, that the true source of disagreement on the Court lies not so much in defining the state interests which may support affirmative action efforts as in defining the degree to which the means employed must 'fit' the ends pursued to meet constitutional standards." 99

The belief that the pursuit of diversity was an appropriate, constitutional goal was not universal. Some argued vehemently that affirmative action was wrong, as it was a form of reverse discrimination that imposed inappropriate burdens on qualified applicants who were denied admission to the educational programs of their choice. ${ }^{100}$ They maintained that

committee, many of whom were members of minority group.").

94. Id. at 313.

95. Id.

96. Scalia, supra note 44 , at 148.

97. 476 U.S. 267 (1986).

98. Id. at 286 (O'Connor, J., concurring) (citing Bakke, 438 U.S. at 311-15).

99. Id. at 287.

100. See, e.g., Stephan Thernstrom \& Abigail Thernstrom, America IN BLACK AND WHITE: ONE NATION INDIVISIBLE 286 (1997) (characterizing the arguments for affirmative action as "an educational disaster" and "the morass in which rigid academic standards sink"); Paul Craig Roberts \& Lawrence M. Stratton, Jr., Color Code, NAT'L REV., Mar. 20, 1995, at 36 (affirmative action is "reverse discrimination [that] violates fundamental norms of justice and fair play"). 
Justice Powell did not speak for the Court and that his opinion should not be deemed controlling. ${ }^{101}$ They also alleged that the license granted by the Powell opinion was being abused by institutions that were treating racial identity not simply as one factor, but rather as the only meaningful consideration in the admissions decisions. ${ }^{102}$

For example, in Hopwood v. State of Texas, ${ }^{103}$ the District Court for the Western District of Texas rejected certain aspects of a University of Texas School of Law admissions process designed to select "the best qualified from the entire minority pool and ... enroll sufficient numbers of those applicants in the entering class to satisfy the" minority enrollment goals it had adopted. ${ }^{104}$ On appeal, the United States Court of Appeals for the Fifth Circuit agreed that the system was flawed. ${ }^{105}$ That court could have confined its ruling to a simple recitation of the ways in which the Texas policy violated the limitations set forth in Bakke. The Texas system did not seem to involve a quota or set-aside for minority students. Nevertheless, it did create a two-track system within which minority applicants were screened by a separate minority applicant subcommittee and, if not admitted initially through that process, were placed on what the court characterized as "segregated waiting lists, dividing applicants by race."106 The law school also used different admissions indices for minority applicants, lowering the threshold in order "to allow the law school to consider and admit more of them." 107 Indeed, at one point in the admissions cycle at issue, the index was lowered even further for Mexican American candidates "in order to admit more of this group." 108

The Hopwood panel did not, however, simply recite these facts and hold that the policy was not narrowly tailored. Instead, it declared that "Justice Powell's view in Bakke is not binding precedent on this issue" and "that any consideration of race or ethnicity by the law school for the purpose of achieving a diverse student body is not a compelling interest under the

101. See, e.g., Carl Cohen, Preference by Race in University Admissions and the Quest for Diversity, 54 WASH. U. J. URB. \& CONTEMP. L. 43, 51 (1998) ("This defense of intellectual diversity as a support for state-imposed racial classifications was shared by no other member of the Court in Bakke and by no justice of the U.S. Supreme Court from that time to this. Justice Powell is lonely in relying upon it.").

102. See, e.g., Lino A. Graglia, The "Affirmative Action" Fraud, 54 WASH. U.J. URB. \& CONTEMP. L. 31, 31-32 (1998) ("The whole point of all racial preference programs is to evade and camouflage the fact that the groups preferred by the programs cannot otherwise compete with others for admission to selective institutions of higher education on the basis of the standard criteria for academic achievement or ability.").

103. Hopwood v. Texas, 861 F. Supp. 551 (W.D. Tex 1994).

104. Id. at 578.

105. Hopwood v. Texas, 78 F.3d 932 (5th Cir. 1996).

106. Id. at 938 .

107. Id. at 936 .

108. Id. at 936 n.6. 
Fourteenth Amendment." 109

This bold challenge to the accepted wisdom made Hopwood the most visible of a series of decisions in which the constitutional issues were raised and conflicting results reached. The Court of Appeals for the Ninth Circuit, for example, refused to repudiate Bakke. ${ }^{110}$ It conceded that there had been important developments since Bakke, especially at the Supreme Court level where "the Court has not looked upon race-based factors with much favor." 111 It concluded, however, that it was for the Supreme Court itself to "declare that the Bakke rationale regarding university admissions policies has become moribund" and that "[f]or now... it ineluctably follows that the Fourteenth Amendment permits University admissions programs which consider race for other than remedial purposes, and educational diversity is a compelling governmental interest that meets the demands of strict scrutiny of race-conscious measures." 112

A different approach was taken in the Court of Appeals for the Eleventh Circuit. In Johnson v. Board of Regents of the University of Georgia, it characterized the status of diversity as a compelling interest as "an open question." 113 It declared, however, that "[w]e need not, and do not, resolve... whether student body diversity ever may be a compelling interest supporting a university's consideration of race in its admissions process." 114 Instead, it held that the policy was not narrowly tailored. The court stressed that the University "mechanically and inexorably award[ed] an arbitrary 'diversity' bonus to each and every non-white applicant... and severely limit[ed] the range of other factors that may be considered ...."115 This meant that the "policy contemplates that nonwhite applicants will be admitted or advance further in the [evaluation] process at the expense of white applicants with greater potential to contribute to a diverse student body. This lack of flexibility is fatal to UGA's policy." 116

At the same time, a parallel set of developments took place at the polls, where the general public voiced consistent opposition to affirmative action.

109. Id. at 944 .

110. See Smith v. Univ. of Wash. Law Sch., 233 F.3d 1188, 1201 (9th Cir. 2000) ("at our level of the judicial system[,] Justice Powell's opinion remains the law"), cert. denied, 532 U.S. 1051 (2001).

111. Smith, 233 F.3d at 1200 (citing Adarand Constructors v. Pena, 515 U.S. 200, 227 (1994); City of Richmond v. J.A. Croson Co., 488 U.S. 469, 493 (1989)).

112. Smith, 233 F.3d at 1200-01. The Court also noted that the challenge to the policy at issue had been rendered moot by the intervening vote by the people of Washington to bar "'preferential treatment' to any individual 'on the basis of race." Id. at 1201 .

113. 263 F.3d 1234, 1250 (11th Cir. 2001).

114. Id. at 1244 .

115. Id. at 1254 .

116. Id. 
In California, for example, Proposition 209 declared that "[ $t]$ he state shall not discriminate against, or grant preferential treatment to, any individual or group on the basis of race, sex, color, ethnicity, or national origin in the operation of public employment, public education, or public contracting." 117 It was approved by fifty-four percent of the individuals voting. ${ }^{118}$ In a similar vein, the voters in Washington state approved Initiative Measure No. 200 by an equally robust margin. ${ }^{119}$ It used the same language, banning "discrimination" and "preferential treatment."120

These developments suggested that a reexamination of the issues was in order, and the foes of affirmative action were only too happy to oblige. The primary challenge came from the Center for Individual Rights, the public interest litigation group that had brought the Hopwood litigation. It selected the University of Michigan as its next target, filing challenges to the admissions policies employed by its Law School and College of Literature, Science, and the Arts (LSA). That decision turned out to be particularly significant.

\section{Diversity at the University of Michigan Pre-Grutter and Gratz}

In the late 1980s, the University of Michigan made a significant commitment to affirmative action and diversity when it adopted the Michigan Mandate, a program premised on the assumption that diversity will become the cornerstone in efforts "to achieve excellence in teaching, research, and service in the years ahead." 121 The Mandate envisioned a wide range of affirmative measures. As one University administrator noted, "[t]he fundamental principle of the mandate was that the university should become a leader in creating a multicultural community that could serve as a model for society as well as for higher education." 122 One

117. CAL. CONST. art. I, § 31(a) (1996). A legal challenge was unsuccessful. See Coal. for Econ. Equity v. Wilson, 946 F. Supp. 1480 (N.D. Cal. 1996), vacated, 110 F.3d 1431 (9th Cir.), amended and superseded by 122 F.3d 692 (9th Cir.), stay denied, 122 F.3d 718 (9th Cir.), cert. denied, 521 U.S. 1141 (1997).

118. See Robert Pear, In California, Foes of Affirmative Action See a New Day, N.Y. Times, Nov. 7, 1996, at B7.

119. See Sam Howe Verhovek \& B. Drummond Ayres, Jr., The 1998 Elections: The Nation-Referendums; Voters Back End to State Preferences, N.Y. TIMES, Nov. 4, 1998 , at B2 (noting that the measure was "running ahead, 60 percent to 40 percent").

120. WASH. REV. CODE ANN. $\S 49.60 .400$ (West 2008) ("The state shall not discriminate against, or grant preferential treatment to, any individual or group . . .."). Similar measures would eventually be approved in Nebraska and, notably, Michigan. See infra text accompanying notes 351-360.

121. James J. Duderstadt, The Michigan Mandate: A Strategic Linking of ACADEMIC EXCELlENCE AND Social Diversity 1 (1990) (Draft 6.0) [hereinafter DUDERSTADT, MANDATE: A STRATEGIC LINKING].

122. Earl Lewis, Why History Remains a Factor in the Search for Racial Equality, in DEFENDING DIVERSITY: AfFIRMATIVE ACTION AT THE UNIVERSITY OF MICHIGAN, at 17, 55 (Patricia Gurin et al. eds., 2004). 
integral aspect of this was the desire to "achieve increases in the number of entering under-represented minority students, as well as in our total underrepresented minority enrollment." 123

Consistent with this, both the Law School and LSA adopted detailed affirmative admissions policies. In particular, the Law School declared its intention "to 'achieve that diversity which has the potential to enrich everyone's education and thus make a law school class stronger than the sum of its parts." 124 This focus on the benefits of a diverse learning environment was in some respects a departure from the strict terms of the Mandate, which spoke largely in terms of moral justifications. ${ }^{125}$ It would, however, prove to be a crucial decision. In the face of the attacks brought by CIR, the Law School and University mounted what one observer characterized as a "full-throated counteroffensive," a vigorous response that included "the marshaling of statistical evidence of the benefits of racial diversity." 126 As one University official noted, "[t]he lawsuits, ironically, did force the university to clarify what it had been doing and why, and to articulate a rationale for the educational benefits of diversity." 127

Two separate cases were filed and two different results emerged at the district court level. In the first decision, Gratz v. Bollinger, ${ }^{128}$ District Judge Patrick Duggan held that the Powell opinion in Bakke controlled, ${ }^{129}$ that the University had established that diversity was a "compelling governmental interest under strict scrutiny," 130 and that the LSA policy withstood the rigors of a narrow tailoring analysis. ${ }^{131}$ In the second decision, Grutter v. Bollinger, ${ }^{132}$ a different district judge, Bernard Friedman, concluded that Justice Powell did not speak for the Court in Bakke and "that under the Supreme Court's post-Bakke decisions, the achievement of such diversity is not a compelling state interest because it is not a remedy for past discrimination." "133 Judge Friedman did acknowledge

123. DuderstADT, MANDATE: A STRATEGIC LINKING, supra note 121 , at 16.

124. Grutter, 539 U.S. at 315 (quoting the Law School policy).

125. See, e.g., James J. Duderstadt, The Michigan Mandate: A SEven-year PROGRESS REPORT 1987-1994, at 3 (1995) ("Fundamentally, it is the morally right thing to do."); DuDERSTADT, MANDATE: A STRATEGIC LINKING, supra note 121, at 3 ("First and foremost, the ... commitment to affirmative action and equal opportunity is based on our fundamental social, institutional, and scholarly commitment to freedom, democracy, and social justice.").

126. Steven A. Holmes, A New Turn in Defense of Affirmative Action, N.Y. TIMES, May 11, 1999, at A1.

127. Lewis, supra note 122, at 55 .

128. 122 F. Supp. 2d 811 (E.D. Mich. 2000).

129. Id. at $817-22$

130. Id. at 824 .

131. Id. at 824-33.

132. 137 F. Supp. 2d 821 (E.D. Mich. 2001).

133. Id. at 849 . 
that "diversity [has] important educational benefits."134 But he ruled that the Law School's "use of race has not been ... narrowly tailored at any time under consideration in this case.".135

Both decisions were appealed to the Court of Appeals for the Sixth Circuit, which subsequently decided only one of the two, Grutter. ${ }^{136}$ The court considered the case en banc and was bitterly divided. ${ }^{137}$ Five judges held that Bakke provided the appropriate analytic matrix and that "the Law School's consideration of race and ethnicity is virtually indistinguishable from the Harvard plan Justice Powell approved in Bakke."138 Four disagreed, arguing that Bakke did not control, that diversity was not a compelling interest, and that even if it were the law school policy was not narrowly tailored. ${ }^{139}$

This set the stage for a reexamination of these issues by the Supreme Court, which "granted certiorari ... to resolve the disagreement among the Courts of Appeals on a question of national importance: Whether diversity is a compelling interest that can justify the narrowly tailored use of race in selecting applicants for admission to public universities." 140 In a highly unusual move, the Court also agreed to hear Gratz "despite the fact that the Court of Appeals had not yet rendered a judgment, so that this Court could address the constitutionality of race in university admissions in a wider range of circumstances."14l

\section{E. The Shift to Fact-Based Analysis in Grutter and Gratz}

The two cases were argued together and decided on the same day, albeit in separate opinions. The key decision was Grutter. Justice O'Connor, writing for herself and Justices Stevens, Souter, Ginsburg, and Breyer, disclaimed any need to determine if Justice Powell had in fact spoken for the Court in Bakke. ${ }^{142}$ She preferred instead, "for the reasons set out

134. Id.

135. Id. at 850 .

136. Grutter v. Bollinger, 288 F.3d 732 (6th Cir. 2002) (en banc).

137. Those disagreements involved both fundamentally different views regarding the operative doctrines, see, e.g., id. at 788 (Boggs, J., dissenting) ("the majority has given us now argument as to why the engineering of a diverse student body should be a compelling interest sufficient to satisfy strict scrutiny"), and accusations of bad faith in how the case was handled. Id. at 810-14 (Boggs, J., dissenting) ("Procedural Appendix").

138. Id. at 747 .

139. Id. at 793 (Boggs, J., dissenting) (diversity principle "poorly defined" and lacks a "logical stopping point"); id. at 815-18 (Gilman, J., dissenting) (stating that the policy was not narrowly tailored).

140. Grutter v. Bollinger, 539 U.S. 306, 322 (2003).

141. Gratz v. Bollinger, 539 U.S. 244, 260 (2003).

142. Grutter, 539 U.S. at 325 ("We do not find it necessary to decide whether Justice Powell's opinion is binding under Marks."). The reference is to the rule 
below," to simply "endorse [his] view that student body diversity is a compelling state interest that can justify the use of race in university admissions." ${ }^{43}$ The manner in which she went about this, however, departed in significant ways from the approach taken by Justice Powell.

Justice O'Connor accepted the University's argument that "the educational benefits that diversity is designed to produce" are "substantial."144 Quoting the district court, and echoing views expressed fifty-three years earlier in Sweatt, ${ }^{145}$ she found that:

[T] he Law School's admissions policy promotes "cross-racial understanding," helps to break down racial stereotypes, and "enables [students] to better understand persons of different races." ... These benefits are "important and laudable," because "classroom discussion is livelier, more spirited, and simply more enlightening and interesting" when the students have "the greatest possible variety of backgrounds." 146

She noted that "numerous studies show that student body diversity promotes learning outcomes, and 'better prepares students for an increasingly diverse workforce and society, and better prepares them as professionals." "147 And she stressed that "[t]hese benefits are not theoretical but real, as major American businesses have made clear that the skills needed in today's increasingly global marketplace can only be developed through exposure to widely diverse people, cultures, ideas, and viewpoints." 148 As one prominent social scientist has observed, the approach embraced by Justice O'Connor was "a victory for higher education research," with "the evidence about the need for racial diversity in education ... . cited as compelling evidence by both the appellate court judge in the undergraduate case and by the Supreme Court, with Sandra

articulated in Marks v. United States, 430 U.S. 188 (1977), which states that "[w] wen a fragmented Court decides a case and no single rationale explaining the result enjoys the assent of five Justices, 'the holding of the Court may be viewed as that position taken by those members who concurred on the narrowest grounds."' Id. at 193 (quoting Gregg v. Georgia, 428 U.S. 153, 169 n.15 (1976)).

143. Grutter, 539 U.S. at 325 . There is some dispute about whether diversity commanded a sixth vote, that of Justice Kennedy, who observed in his dissenting opinion that "[o]ur precedents provide a basis for the Court's acceptance of a university's considered judgment that racial diversity among students can further its educational task, when supported by empirical evidence." Id. at 387-88 (Kennedy, J., dissenting).

144. Id. at 330.

145. Sweatt v. Painter, 339 U.S. 629 (1950). See supra text accompanying note 68.

146. Grutter, 539 U.S. at 330.

147. Id. (quoting Brief for American Educational Research Association et al. as Amici Curiae Supporting Respondents at 3).

148. Id. (citing Brief for $3 \mathrm{M}$ et al. as Amici Curiae Supporting Respondents at 5; Brief for General Motors Corporation as Amicus Curiae Supporting Respondents at 34). 
Day O'Connor writing the opinion for the majority in Grutter . . .."149

The Court's clear and unambiguous embrace of diversity as a compelling interest was significant. It was, however, only the necessary first step. The operative standard of review was strict scrutiny, which meant that the admissions policy would be "constitutional only if [it is] narrowly tailored to further [the] compelling" interest sought. ${ }^{150}$ Justice O'Connor found "that the Law School's admission program bears the hallmarks of a narrowly tailored plan," employing "race or ethnicity ... flexibly as a "plus' factor in the context of individualized consideration of each and every applicant."151 The Law School, she stressed, "engages in a highly individualized, holistic review of each applicant's file, giving serious consideration to all the ways an applicant might contribute to a diverse educational environment" and "affords this individualized consideration to applicants of all races." 152

The Law School also established that it had complied with three additional requirements. First, it had engaged in a "serious, good faith consideration of workable race-neutral alternatives that will achieve the diversity the university seeks." 153 Second, its approach did not, at least in Justice O'Connor's estimation, "unduly harm members of any racial group," given "its individualized inquiry into the possible diversity contributions of all applicants...."154 Third, she stressed that the Law School itself had recognized that its "race-conscious polic[y] must be limited in time," 155 a general requirement that "can be met by sunset provisions . . . and periodic reviews to determine whether racial preferences are still necessary to achieve student body diversity." 156 Further, she observed, in what would prove to be a controversial statement, the legal force of which has been debated, that "[w]e expect that 25 years from now, the use of racial preferences will no longer be necessary to further the

149. Sylvia Hurtado, Linking Diversity with the Educational and Civic Missions of Higher Education, 30 REV. HIGHER EDUC. 185, 188 (2007) [hereinafter Hurtado, Linking Diversity].

150. Grutter v. Bollinger, 539 U.S. 306, 326 (2003).

151. Id. at 334 .

152. Id. at 337. For an argument that the O'Connor approach to narrow tailoring both changes how such matters should be done and is incorrect, see Ian Ayres \& Sydney Foster, Don't Tell, Don't Ask: Narrow Tailoring After Grutter and Gratz, 85 TEX. L. REV. 517 (2007).

153. Grutter, 539 U.S. at 339. For an extensive discussion of this requirement, see George La Noue \& Kenneth L. Marcus, Serious Consideration of Race-Neutral Alternatives in Higher Education, 57 CATH. U. L. REV. 991 (2008). They conclude that " $[w]$ hether the defendant institution has engaged in the kind of program evaluation that has seriously considered race-neutral alternatives may well be decisive in the future litigation and OCR investigations." Id. at 1044.

154. Grutter, 539 U.S. at 341.

155. Id. at 342 .

156. Id. 
interest approved today."157

The companion case was Gratz v. Bollinger, ${ }^{158}$ in which the Court considered the system employed by Michigan's primary undergraduate unit, the College of Literature, Science, and the Arts (LSA). The focus here was on the policy in effect at the time the plaintiffs applied, ${ }^{159}$ which used a point system to determine who would be admitted. That system assigned a set number of points to various factors. In particular, it "automatically distribut[ed] 20 points" of the 100 required for admission "to every single applicant from an 'underrepresented minority' group, as defined by the University." 160

Writing for a different majority, ${ }^{161}$ Chief Justice Rehnquist conceded that Grutter resolved the compelling interest question. ${ }^{162}$ But he found that the LSA system was not narrowly tailored. He stressed that a constitutionally permissible system would make certain that "each characteristic of a particular applicant [should] be considered in assessing the applicant's entire application." "163 The net result of the LSA approach was, he believed, to " $\operatorname{mak}[\mathrm{e}]$ 'the factor of race ... decisive' for virtually every minimally qualified minority applicant."164 Indeed, he stressed, "the University" itself "has conceded [that] the effect . . . is that virtually every qualified underrepresented minority applicant is admitted." 165

The University disagreed. It argued that "the fact that every minority applicant receives the same 'plus' hardly means that race plays the same role in the admissions outcome for each applicant." 166 It maintained that

157. Id. at 343 . The suggestion that there should be a 25 year limit has been downplayed. See, e.g., Vikram David Amar \& Evan Caminker, Constitutional Sunsetting?: Justice O'Connor's Closing Comments in Grutter, 30 HASTINGS Const. L.Q. 541 (2003). One recent study stresses that the real problem lies elsewhere, noting that "substantial progress in increasing black students' pre-collegiate performance is critical to any hope of eliminating the need for affirmative action within the next generation." Alan Krueger \& Jesse Rothstein, Race, Income, and Colleges in 25 Years: Evaluating Justice O'Connor's Conjecture, 8 AM. L. \& ECON. REV. 282, 309-10 (2006). For an eloquent explanation of why the problem is not new, nor likely to change, see Donald P. Judges, Bayonets for the Wounded: Constitutional Paradigms and Disadvantaged Neighborhoods, 19 HASTINGS CONST. L. Q. 599 (1992).

158. 539 U.S. 244 (2003).

159. The Court noted that " $[t]$ he University has changed its admissions guidelines a number of times during the period relevant to this litigation ...." Id. at 253.

160. Id. at 271.

161. The four dissenters in Grutter-Chief Justice Rehnquist and Justices Scalia, Kennedy, and Thomas - were joined by Justices O'Connor and Breyer.

162. Gratz, 539 U.S. at 268 ("for the reasons set forth today . . the Court has rejected" the argument that diversity is not a compelling interest).

163. Id. at 271. He did not, however, cite Grutter for this proposition. Rather, he drew on Justice Powell's Bakke opinion.

164. Id. at 272 .

165. Id. at 273.

166. Brief for Respondents at 37, Gratz v. Bollinger, 539 U.S. 244 (2003) (No. 02- 
the LSA formula was "flexible" and " considered all pertinent elements of diversity in light of the particular qualifications of each applicant ...."'167 The sheer weight accorded to race was nevertheless clearly troubling. The Chief Justice complained, for example, that "[e]ven if" a student's "'extraordinary artistic talent' rivaled that of a Monet or Picasso, the applicant would receive, at most, five points under LSA's system." 168 The net effect, he concluded, was that any possible "individualized review" occurred "only ... after admissions counselors automatically distribute the University's version of a 'plus' that makes race a decisive factor for virtually every minimally qualified underrepresented minority applicant." "169

Justice O'Connor agreed. In a concurring opinion that Justice Breyer joined, she stressed that LSA had failed to provide "the necessary individualized consideration." 170 The other three members of the Grutter majority disagreed, arguing in particular that the LSA point system was an "accurately described, fully disclosed ... affirmative action program,",171 one that "lets all applicants compete for all places and values an applicant's offering for any place not only on grounds of race" but on a myriad number of factors. ${ }^{172}$ In particular, Justice Souter declared that a twenty, as opposed to, for example, a ten point "plus factor" for race was, at best, "suspicious." 173 Any credible doubts, he maintained, could be resolved by a remand directed toward gathering additional evidence about how the process actually operated. ${ }^{174}$ Those pleas fell on deaf ears. The majority held that the LSA system was "not narrowly tailored to achieve ... [the] asserted compelling interest in diversity"175 and was, accordingly, unconstitutional.

\section{GRUTTER EQUALS "BAKKE, WITH TEETH"}

The brief summary of the evolution and treatment of the diversity rationale that $I$ have provided in Part I of this article does not exhaust the range of issues raised and debated in the history of affirmative action and diversity, much less in Grutter and Gratz. There were thirteen separate opinions in the two cases. Seven of the justices wrote twice, with only

516).

167. Id. at 38 (quoting Regents of the Univ. of Cal. v. Bakke, 438 U.S. 265, 317 (1978)).

168. Gratz v. Bollinger, 539 U.S. 244, 273 (2003).

169. Id. at 274 (emphasis in original).

170. Id. at 280 (O'Connor, J., concurring).

171. Id. at 305 (Ginsburg, J., dissenting).

172. Id. at 293 (Souter, J., dissenting).

173. Id. at 296 (Souter, J., dissenting).

174. Gratz v. Bollinger, 539 U.S. 244, 296-97 (2003) (Souter, J., dissenting).

175. Id. at 275 . 
Justices Scalia and Kennedy confining themselves to a single expression of concurrence and dissent.

However, two important points emerge, at least as matters currently stand. ${ }^{176}$ First, the Court has now held, clearly and unequivocally, that diversity is a compelling educational interest for the purposes of college or university admissions decisions. ${ }^{177}$ That is the law of the land and will remain so unless and until the Court itself retreats from that position. In this respect, higher education arguably now finds itself in the same position that elementary and secondary education did in the wake of Brown. ${ }^{178}$

Second, in the wake of Grutter and Gratz, it is not enough for an institution to simply declare that diversity is a goal and then take race or ethnicity into account however it chooses as it fashions its entering classes. It must embrace diversity as an integral part of its mission. Further, it must do so for educational reasons, and not to correct for "societal discrimination"179 or to achieve "racial balancing."180 Institutions must craft race-conscious admissions policies in a carefully controlled way, openly linking the particular approach it takes to its educational goals and the specific outcomes it wishes to attain.

176. Various developments since the decisions were handed down counsel caution regarding both the implications and the long-term viability of Grutter and Gratz. Justice O'Connor, for example, has retired and her seat on the Court has been taken by Justice Samuel A. Alito, Jr. Justice Alito has not yet written an opinion in this area, but he joined, apparently without reservation, Chief Justice John J. Roberts, Jr.'s opinion for the Court in Parents Involved in Community Schools v. Seattle School District No. 1, 551 U.S. 701 (2007). The Chief Justice acknowledged that the Court has "recognized as compelling for the purposes of strict scrutiny ... the interest in diversity in higher education...." Id. at 722 (citing Grutter, 539 U.S. at 328). But he went on to declare that "[t]he way to stop discrimination on the basis of race is to stop discriminating on the basis of race," Id at 748 . This formulation does not bode well for continuing acceptance of the diversity rationale, if and when the issue returns to the Court. The recent replacement of Justice David H. Souter by Justice Sonia Sotomayor does not materially change matters, arguably leaving the issue in the sometimes mercurial hands of Justice Anthony M. Kennedy.

177. The holdings expressly did not extend beyond the admissions decision, a point Justice Scalia stressed in his dissent in Grutter. See Grutter, 539 U.S. at 349 (Scalia, J., dissenting).

178. I say arguably because the parallels between the two cases are not exact ones. The Brown Court was unanimous; the Grutter Court was deeply divided. Chief Justice Earl Warren, the author of the Brown opinion, and the primary force behind its unanimity, did not resign until 1969, while Justice O'Connor left the Court a scant three years after writing the Grutter opinion, replaced by Justice Alito, whose support for the diversity principle will, if anything, be a matter of stare decisis rather than conviction.

179. See Grutter, 539 U.S. at 323-24 (noting that Justice Powell's Bakke opinion "rejected as an interest remedying societal discrimination").

180. See id. at 329-30 (rejecting diversity plans that seek "some specified percentage of a particular group" as "outright racial balancing, which is patently unconstitutional"). 
These would normally be regarded as the natural requirements of sound educational policy and practice. The reality is, however, that many of these principles are often ignored. I will now argue, accordingly, that higher education must take two critical factors into account as it crafts the sort of race-conscious admissions policies that Grutter contemplates.

The first is that Justice O'Connor's emphasis on the notion that the benefits of diversity are "real" should put higher education on notice that admissions policies that employ preferences are now subject to a much more rigorous evaluation standard that the one that prevailed in the years between Bakke and Grutter. It is no longer enough to theorize that actual education outcomes will ensue. Rather, institutions that undertake racebased admissions must acknowledge and account for the reality that their ability to defend such policies and practices now depends on their ability to demonstrate that the benefits associated with those policies and procedures are actually occurring. ${ }^{181}$

The second is that it would be a mistake to assume that judicial treatment of future challenges to either the diversity principle itself or a particular admissions policy will be in any meaningful respects "deferential." Justice O'Connor did state that "[t]he Law [S]chool's educational judgment that such diversity is essential to its educational mission is one to which we defer." 182 As I will stress, however, read with care and in context, that statement does nothing more than leave as a matter of educational choice a given institution's decision about the mission it wishes to pursue. It does not in fact relieve that institution of the obligation to comply with the rigors of strict scrutiny.

\section{A. The Benefits of Diversity "Are Real"}

If we compare the approach taken by Justice Powell in his Bakke opinion with that of Justice O'Connor in Grutter, it becomes clear that Grutter is Bakke with teeth. Justice Powell did stress that "[r]acial and ethnic distinctions of any sort are inherently suspect and this calls for the most exacting judicial examination." ${ }^{83} \mathrm{He}$ did not, however, consistently

181. In effect, I am arguing that this is one of the "hallmarks" of narrow tailoring, see supra text accompanying note 31 , and should be expressly added to the list spelled out by Justice O'Connor. I acknowledge, as Professor Goodwin Liu stressed in a thoughtful review of this Article, that in many important respects the University of Michigan was not required to meet this burden, and that much of the social science evidence it relied on in making its case was not actually reviewed by the Court in any meaningful manner. I believe, however, that the landscape has changed. I believe that institutions should act in this manner as a matter of course and not simply as a litigation strategy. That said, I also believe, and argue in this Article, that the courts must now pay much closer attention to these matters.

182. Grutter v. Bollinger, 539 U.S. 306, 328 (2003).

183. Regents of the Univ. of Cal. v. Bakke, 438 U.S. 265, 291(1978) (opinion of Powell, J.). 
employ the language and approaches of strict scrutiny in his discussion of diversity as a "constitutionally permissible" 184 interest. Nor did he characterize his examination of the various aspects of the Davis plan that he found objectionable as an assessment of the extent to which the program was not "narrowly tailored."

Instead, Justice Powell did two things. First, he discussed the extent to which "[a]cademic freedom," which he characterized as "a special concern of the First Amendment," 185 allowed a college or university "to make its own judgments as to education includ[ing] the selection of its student body." 186 Then he offered the "illuminating example" of the admissions program at Harvard College, which takes "race into account in achieving the educational diversity valued by the First Amendment ...."187 $\mathrm{He}$ quoted the Harvard policy at some length and then discussed it in general terms, concluding that it "treats each applicant as an individual in the admissions process." 188 The net effect, he stated, was that the qualifications of an "applicant who loses out ... would have been weighed fairly and competitively, and he would have no basis to complain of unequal treatment under the Fourteenth Amendment." 89

Justice Powell simply took as gospel the text preached by the higher education establishment. He did not require that the parties supporting affirmative action and diversity actually document the extent to which their intuition about these matters was supported by a detailed accounting of the actual benefits that would be attained. Nor did he ask them to provide any evidence that such outcomes actually occurred. Rather, he simply accepted the premise of the Harvard policy, that students with different "background $[s]$ and outlook[s]" bring an undefined "something" with them when they matriculate. ${ }^{190}$

Justice O'Connor did something quite different. She did not simply note and embrace the Michigan Law School plan as an "example" to be followed. Instead, she made the transition from educational theory to educational fact, stressing that the actual benefits for all students enrolled in a racially diverse educational setting are "substantial" and are "not theoretical but real."191 She found support for this in a variety of forms, including: evidence adduced at trial about actual results;" 192 "numerous

184. Id. at 311-12.

185. Id. at 312 .

186. Id.

187. Id. at 316 .

188. Id. at 318 .

189. Bakke, 438 U.S. at 318.

190. Id. at 323 (quoting the Harvard College Admissions Program statement).

191. Grutter v. Bollinger, 539 U.S. 306, 330 (2003).

192. Id. 
studies that show that student diversity promotes learning outcomes"; 193 and the perspectives offered by various amici that documented the positive, post-graduation effects flowing from "exposure to widely diverse people, cultures, ideas, and viewpoints." 194

Michigan and its amici consciously developed, and Justice O'Connor appears to have been persuaded by, detailed evidentiary support for its claim that diversity had real, demonstrable, and positive effects. This stood in stark contrast to the evidence accepted by Justice Powell. For example, the Harvard College policy he quoted at length spoke in general terms about the ability of "[a] farm boy from Idaho" and "a black student" to "bring something" to Harvard that "a white person cannot offer." 195 The only other "evidence" offered in support of diversity's educational effects was equally vague, with the then-President of Princeton University outlining various types of "informal" learning that might flow from "unplanned, casual encounters." 196

Justice Powell's rather cursory treatment of the narrow tailoring inquiry also contrasts sharply with the approach taken by Justice O'Connor. Some of this is almost certainly due to the evolution of Equal Protection doctrines over the twenty-six years between Bakke and Grutter. Strict scrutiny was an accepted fact when Bakke was decided in $1977 .{ }^{197}$ Its current parameters are, however, more detailed and demanding in the light of intervening cases. ${ }^{198}$ The extent to which the present analytic framework is especially demanding is revealed in the four very specific requirements for narrow tailoring emphasized in the O'Connor opinion: truly individualized evaluation; ${ }^{199}$ careful examination of race neutral alternatives before adopting a race-conscious policy; ${ }^{200}$ the need to avoid inflicting harm on

193. Id.

194. Id. at 330-33.

195. Regents of the Univ. of Cal. v. Bakke, 438 U.S. 265, 316 (1978) (quoting the Harvard College Admissions Program statement).

196. Id. at 312 n.43 (quoting William Bowen, Admissions and the Relevance of Race, PrINCETON AlUMNI WEEKLY, Sept. 26, 1977, at 7, 9).

197. Justice Powell acknowledged this when he noted that "[r]acial and ethnic distinctions of any sort are inherently suspect and thus call for the most exacting judicial scrutiny." Bakke, 438 U.S. at 291. And he refused to accept the University's contention that a different standard should be apply. See id. at $294-99$ (discussing the argument that "discrimination against members of the white 'majority' cannot be suspect if its purpose can be characterized as "benign." ").

198. See, in particular, City of Richmond v. J.A. Croson Co., 488 U.S. 469, 493 (1989) (stressing the need to apply strict scrutiny as the only "way of determining what classifications are 'benign' or 'remedial' and what classifications are in fact motivated by illegitimate notions of racial inferiority or simple racial politics'), and Adarand Constructors, Inc. v. Pena, 515 U.S. 200, 226 (1995) (emphasizing the need to subject all affirmative measures to strict scrutiny).

199. Grutter, 539 U.S. at 334-39.

200. Id. at $339-40$. 
other applicants; ${ }^{201}$ and recognition that the program must be limited in duration and subject to periodic, rigorous review. ${ }^{202}$

Justice Powell alluded to various aspects of these elements in his discussion. ${ }^{203}$ But he did not couch his analysis in these terms. Nor did he in any meaningful sense make compliance with such standards mandatory. Justice O'Connor noted as much when she observed that "[s]ince Bakke we have had no occasion to define the contours of the narrow-tailoring inquiry with respect to race-conscious university admissions programs."204 She then emphasized the nature of what she characterized as "the hallmarks of a narrowly tailored plan" 205 in a highly detailed, ten page discussion of the Michigan approach.

The differences between the Powell and O'Connor opinions are, then, pronounced and important. Justice Powell was willing to accept at face value the what the pro-diversity litigants before him maintained. Justice O'Connor did not. Rather, she wrote an opinion within which these matters are treated as fact rather than intuition. It was on that basis that she accepted the argument that diversity is a compelling educational interest. And it is in the light of that approach that affirmative admissions policies will be judged in the future.

\section{B. Grutter Allows Judicial Deference Only to an Institution's Chosen Mission}

One controversial element of the O'Connor opinion was her statement that "[t]he Law School's educational judgment that such diversity is essential to its educational mission is one to which we defer."206 Justice Kennedy was especially outraged, believing that this marked a sharp departure from the rigors of strict scrutiny and that the Court's "review" of these matters was "nothing short of perfunctory."207 Some commentators agree with Kennedy, alleging, for example, that "the Court has effectively dropped the standard of review from strict scrutiny to rational basis review."208

201. Id. at 341 .

202. Id. at $341-43$.

203. See, e.g., Bakke, 438 U.S. at 317 (opinion of Powell, J.) (expressing support for admissions programs that are "flexible enough to consider all pertinent elements of diversity in light of the particular qualifications of each applicant").

204. Grutter v. Bollinger, 539 U.S. 306, 333 (2003).

205. Id. at 334 .

206. Id. at 328 .

207. Id. at 388 (Kennedy, J. dissenting). See also id. at 356 (Thomas, J., dissenting) (characterizing the majority's analysis as "conclusory").

208. Lackland H. Bloom, Jr., Grutter and Gratz: A Critical Analysis, 41 Hous. L. REV. 459, 468 (2004). See also JoInT STATEMENT, supra note 21, at 5 (noting the deference language and stressing that the opinion "establishes a presumption of good faith on the part of universities in selecting their student bodies"); Pamela S. Karlan, 
These criticisms are clearly misplaced. First, the "deference" afforded did not extend to whether diversity itself should be deemed a compelling interest. The precise statement is worth repeating: "The Law School's educational judgment that such diversity is essential to its educational mission is one to which we defer." ${ }^{209}$ Justice O'Connor did not declare that the Law School's judgment that diversity itself is a compelling educational interest is one to "which we defer." Rather, she deferred to Michigan's choice of mission. She quite correctly treated this as something Michigan was free to do. Both Justices Scalia and Thomas recognized this in their dissents. Justice Scalia argued that the real issue was "Michigan's interest in maintaining a 'prestige' law school whose normal admissions standards disproportionately exclude blacks and other minorities." ${ }^{10}$ Justice Thomas agreed, complaining that " $[t]$ he interest in remaining elite and exclusive that the majority thinks so obviously critical requires the use of admissions 'standards' that, in turn, create the .. . 'need' to discriminate on the basis of race." 211

Justice O'Connor's "deference" statement was descriptive. It simply acknowledged that the University of Michigan had chosen to embrace student body diversity as part of its institutional identity. The constitutional question was whether what followed from this decision could withstand strict scrutiny. The first step for Michigan was to define its institutional mission. The second was to structure its admissions policies and practices in ways that would allow it to admit a diverse group of students. It is only at this second stage that the active use of race as a decision-making criterion enters the picture. The focus for Justice O'Connor was then whether the consequences that follow from Michigan's judgments about its educational mission, and its concomitant practices, are constitutional. That is, is the pursuit of student body diversity, achieved through the active consideration of race, in practice a compelling interest?

This becomes clear when we look at what Justice O'Connor actually did in her opinion. The very next sentence after the "deference" statement, sets the stage for what follows: "The Law School's assessment that diversity will, in fact, yield educational benefits is substantiated by respondents and

Compelling Interests/Compelling Institutions: Law School as Constitutional Litigants, 54 UCLA L. REV. 1613, 1622 (2007) ("What is striking here is not that the Court thinks racial diversity within the student body of a selective public educational institution can be a compelling governmental purpose, but rather that it declares that racial diversity is compelling because a school thinks it is."); Luis-Fuentes Rohwer \& Guy-Uriel E. Charles, In Defense of Deference, 21 CONST. COMMENT. 133, 136 (2004) ("In this Essay, we defend the Court's deference to the judgment of educators and admissions officials on the necessity of raceconscious admissions.").

209. Grutter, 539 U.S. at 328 (emphasis added).

210. Id. at 347 (Scalia, J., dissenting).

211. Id. at 361 (Thomas, J., dissenting). 
their amici."212 Justice $\mathrm{O}^{\prime}$ Connor thus makes a quick transition from deference regarding mission to a detailed consideration of the extent to which the means selected to pursue one aspect of that mission are constitutional. That is, is the belief that diversity has constitutionally cognizable benefits supported by the facts? If so, the interest is compelling, which then requires a discussion of the extent to which the particular means selected are narrowly tailored.

Her discussion of these questions was lengthy and detailed. She noted the explicit findings of the District Court, which were based on an extensive record. ${ }^{213}$ She referred to "numerous studies show[ing] that student body diversity promotes learning outcomes and "better prepares students for an increasingly diverse workforce and society, and better prepares them as professionals." 214 She noted the considered judgments of a wide variety of actors to the effect that the benefits of diversity "are not theoretical but real." 215 And she subjected the actual policy to a series of specific narrow tailoring requirements that were discussed at some length. Viewed in this light, whatever respect Justice O'Connor accorded Michigan's educational judgments about its mission did not in reality operate as a justification for setting aside the requirements of strict scrutiny.

The actual discussion was, moreover, far more rigorous and demanding than that applied by Justice Powell in Bakke. The contrast between the two approaches is stark and telling. Justice Powell accepted what he was told. Justice O'Connor in turn described what the University postulated and then explored, in considerable detail, whether the positions embraced were supported by the facts.

Any questions about whether this is the case are easily resolved when one looks with care at any number of decisions in which the Court has engaged in true deferential review. Those cases that make it quite clear that the level of scrutiny in Grutter was far more exacting than the analysis

212. Id. at 328 .

213. See id. at 330 (noting "the expert studies and numerous reports entered into evidence at trial").

214. Id. (quoting Brief for American Educational Research Association et al. as Amici Curiae at 3). Additional sources noted were: WILLIAM G. BOWEN \& DEREK BOK, THE SHAPE OF THE RIVER: LONG-TERM CONSEQUENCES OF CONSIDERING RACE IN COLLEGE AND UNIVERSITY ADMISSIONS (1998); DIVERSITY CHALLENGED: EVIDENCE ON THE IMPACT OF AFFIRMATIVE ACTION (Gary Orfield \& Michael Kurlaender eds., 2001); and COMPELling INTEREST: EXAMINING THE EVIDENCE ON RACIAL DYNAMICS IN Colleges AND UnIVERSITIES (Mitchell J. Chang et al. eds., 2003). The AERA brief and these three books did in fact compile virtually all of the direct social science evidence available at the time. One of the welcome ironies of Grutter and Gratz is that the decisions have spurred a virtual explosion of research in the field.

215. Grutter v. Bollinger, 539 U.S. 306, 330-31 (2003) (citing briefs filed by various corporations and "high-ranking retired officers and civilian leaders of the United States military"). 
undertaken by the Court in any number of other situations.

For example, in Goldman v. Weinberger, ${ }^{216}$ an Orthodox Jew and ordained rabbi pressed his claim that the United States Air Force's refusal to allow him to wear his yarmulke while on duty infringed his First Amendment freedom to exercise his religious beliefs. The Court held that the challenged regulations "reasonably and even-handedly regulate dress in the interest of the military's perceived need for uniformity."217 The majority observed that "[o]ur review of military regulations challenged on First Amendment grounds is far more deferential than constitutional review of similar laws or regulations designed for civilian society."218 It stressed that "[t]he considered professional judgment of the Air Force is that the traditional outfitting of personnel in standardized uniforms encourages the subordination of personal preferences and identities in favor of the overall group mission."219 And, in a key passage, it emphasized that "whether or not expert witnesses may feel that religious exceptions to [the regulation] are desirable is quite beside the point. The desirability of dress regulations in the military is decided by the appropriate military officials, and they are under no constitutional mandate to abandon their considered professional judgment." 220

This is true deference. The majority declared in no uncertain terms that the opinions of the outside world did not matter, expert or otherwise. Once the military determines that a particular course of action is essential, judicial inquiry is at an end. Justice Brennan recognized this in his dissent, where he complained that the Court had "eliminat[ed] in all but name only, judicial review of military regulations that interfere with the fundamental constitutional rights of service personnel." ${ }^{221} \mathrm{He}$ characterized the deference articulated in Goldman as "a subrational-basis standard" and complained that "it seems that the Court will accept" the Air Force's judgment "no matter how absurd or unsupported it may be." 222

The point is not whether the Goldman standard is or is not appropriate. It is rather that examples of true deference abound in the decisions of the Court, including, but not limited to, cases involving the military, primary and secondary education, ${ }^{223}$ and prisons. ${ }^{224}$ In prison litigation, for

216. 475 U.S. 503 (1986).

217. Id. at 510 .

218. Id. at 507 .

219. Id. at 508 .

220. Id. at 509 .

221. Id. at 515 (Brennan, J., dissenting).

220. Goldman v. Weinberger, 475 U.S. 503, 515 (1986).

223. See, e.g., Morse v. Frederick, 551 U.S. 393, 396 (2007) (holding that "schools may take steps to safeguard those entrusted to their care from speech that can reasonably be regarded as encouraging illegal drug use."); Hazelwood Sch. Dist. v. Kuhlmeier, 484 U.S. 260, 273 (1988) (standard for actions governing "schoolsponsored expressive activities" is whether an educator's "actions are reasonably 
example, the search is for a "logical connection" between the "expert opinion" of prison officials and the burden imposed on what would otherwise have been deemed a fundamental right subject to the rigors of strict scrutiny. ${ }^{225}$ That is quite different from what the Court actually did in Grutter, where, given the need to adhere to the rigors of strict scrutiny, the majority felt obliged to discuss at considerable length the extent to which Michigan's educational judgment was supported by the evidence, ascertaining that the educational benefits are "substantial" and "not theoretical but real." 226

Any doubt that this is the case is dispelled by Overton v. Bazzetta, ${ }^{227}$ a prison case decided just one week before Grutter. The issue before the Court was the extent to which prison officials in Michigan could restrict visits to prisoners, in particular visits by their children. The Court recognized that, outside the prison, such measures would burden a fundamental right-namely, the ability "to maintain certain familial relationships, including association among members of an immediate family and association between grandchildren and grandparents." 228 It did not find it necessary to explore the extent to which that right survives imprisonment, however, because the operative standard was whether "the challenged regulations bear a rational relationship to legitimate penological interests." 229 The regulation was accordingly permissible given the "logical connection" between "maintaining internal security" and protecting children from harm. ${ }^{230}$

It is also important to recognize that the post-Grutter Court has insisted that the rigors of strict scrutiny cannot, and should not, be relaxed when decisions based on race are at issue, even in prisons. That was the message conveyed two years after Grutter in Johnson v. California. ${ }^{231}$ Writing for the Court, Justice O'Connor insisted that Grutter stood for the proposition that "strict scrutiny [applies] in every context, even for so-called 'benign' racial classifications." 232 She then refused to apply a rule of deference appropriate in other prison contexts to a policy of racially segregating

related to legitimate pedagogical concerns.").

224. See, e.g., Turner v. Safley, 482 U.S. 78, 89 (1987) (adopting standard that asks whether a burden on a prisoner's fundamental rights was "reasonably related" to "legitimate penological interests").

225. See id. at 92-93.

226. Grutter, 539 U.S. at 330.

227. 539 U.S. 126 (2003).

228. Id. at 131 (citing Moore v. City of East Cleveland, 431 U.S. 494 (1977) (plurality opinion), and Meyer v. Nebraska, 262 U.S. 390 (1923)).

229. Id. at 132 (citing Turner v. Safley, 482 U.S. 78, 89 (1987)).

230. Id. at 133 .

231. 543 U.S. 499 (2005).

232. Id. at 505 . 
prisoners during the initial classification process following incarceration. ${ }^{233}$ The same thing happened when the Court considered an attempt by two K12 school districts to extend the logic of Grutter to those settings and insisted that the rigors of strict scrutiny should apply. ${ }^{234}$

The approach actually taken in Grutter is then far more rigorous than its critics care to admit. Justice O'Connor's use of the term "deference" was unfortunate. ${ }^{235}$ But her actual opinion for the Court did not signal a willingness on its part to blindly accept whatever story Michigan wished to tell, either as an absolute matter, or in the light of how the Court has handled other cases in which what otherwise might have been deemed suspect constitutional issues were adjudicated.

Grutter is then Bakke with teeth. Bakke embraced the assumption that diversity is a compelling interest because certain institutions thought it was a good idea and minority students might bring, for example, an unspecified "something" to the then predominantly white Harvard College. ${ }^{236}$ That view has been replaced by a standard within which diversity is accepted as a compelling interest because the assumptions for which it stands are supported by positive evidence regarding actual outcomes. Narrow tailoring, in turn, has become more than a simple list of the flaws endemic to the quota system employed by UC Davis. Instead, affirmative admissions policies and practices will now be evaluated within a detailed, multi-step matrix that will ask in each instance whether the policy and program at issue comports with "the hallmarks of a narrowly tailored plan." 237

233. Id. at 509-15 (refusing to apply the Turner rule of deference to prison decisions predicated on race).

234. See Parents Involved in Cmty. Sch. v. Seattle Sch. Dist. No. 1, 551 U.S. 701, 744 (2007) ("Such deference "is fundamentally at odds with our equal protection jurisprudence. We put the burden on state actors to demonstrate that their race-based policies are justified." Id. (quoting Johnson v. California, 543 U.S. 499, 506 (2005))).

235. One possible explanation for invoking "deference" is that it offered the majority a way to deal with the problem posed by the Law School's contention that it did not engage in "racial balancing" in the latter stages of a given admissions cycle as it pursued a "critical mass" of minority students. See Grutter, 539 U.S. at 335-36. A careful reading of the opinion reveals that this is the one area where the majority took Michigan at its word, relying on assertions by the law school's admissions officers that, while pursuing a "critical mass," they did not "seek to admit any particular number or percentage of underrepresented minority students." Id. at 318-19 (discussing the testimony of Dennis Shields and Erica Munzel).

236. See supra text accompanying notes 181-188.

237. Grutter v. Bollinger, 539 U.S. 306, 334 (2003). 


\section{INSTITUTIONAL PROGRAMMING AND ASSESSMENT FOR INSTITUTIONS UTILIZING RACE-CONSCIOUS ADMISSIONS POLICIES}

I would be remiss, having argued that Grutter is Bakke with teeth, if I did not then at least sketch out some of the major implications of this reality for higher education. This discussion is not meant to be definitive. Rather, my goal is to outline some threshold considerations and leave a more detailed examination of these concerns to a future article. My core assumption is that a college or university using race as a factor in admissions decisions must clearly articulate how a racially diverse student body supports its institutional mission and must then specify the educational outcomes it expects will flow from such diversity. Further, the institution must construct and implement an institutional plan for measuring whether those outcomes are in fact occurring. ${ }^{238}$

My analysis proceeds in three steps. First, in Part III-A, I note and explain the special significance of Grutter and Gratz for legal education. This focus is natural for me, as I teach in a law school and am very familiar with the assumptions and practices that inform legal education. It is also highly appropriate for two reasons. First, admission to law school is almost invariably a selective process, involving the screening of a large number of applicants seeking a comparatively small number of seats in any given entering class. This means that they likely use preferences much more frequently than might otherwise be the case. ${ }^{239}$ This is an important reality, given that the strictures imposed by Grutter and Gratz apply only when an institution voluntarily adopts race-conscious admissions criteria. Even then, that presumably happens only after it has given "serious, good faith consideration [to] workable race-neutral alternatives that will achieve the

238. The first requirement was both imposed on Michigan and met by it. The second, as Professor Liu correctly notes, is a burden that the Court did not actually impose on Michigan. That is in some respects unfortunate. It also likely reflects the fact that resolving the wider question of diversity as a compelling interest per se was far more important at that point than holding Michigan's feet to the fire regarding the details of the evidence they offered. Indeed, this "next generation" issue may well be one of the reasons why the nature and force of the social science evidence received much greater attention in Parents Involved. See Parents Involved in Cmty. Sch. v. Seattle Sch. Dist. No. 1, 552 U.S. 701, 760-767 (2007); id. at 837-840, 850-852 (Breyer, J., dissenting).

239. Bowen and Bok, for example, stressed that "[o]ne of the most common misunderstandings concerns the number of institutions that actually take account of race in making admissions decisions. Many people are unaware of how few colleges and universities have enough applications to be able to pick and choose among them." BOWEN \& BOK, supra note 214 , at 15 . They concede that "[t]here is no single, unambiguous way of identifying the number of such schools, but we estimate that only about 20 to 30 percent of all four-year colleges and universities are in this category." Id. 
diversity the [institution] seeks." 240

Simply put, law schools are precisely the sorts of institutions most likely to find themselves confronting the problems posed by the adoption of raceconscious admissions policies, even if they do not aspire to the "elite"241 status of an institution like the University of Michigan Law School. Moreover, given changes in the law school accreditation standards adopted by the American Bar Association in response to Grutter and Gratz, ${ }^{242}$ law schools now find themselves in a world within which the active pursuit of diversity appears to be a mandate, rather than an option. Law schools will also soon find themselves confronting the implications of an additional, pending ABA shift in accreditation focus, from an input to an output based approach. ${ }^{243}$ This is in some respects not a new experience, since law schools have always had to take into account a post-graduation screening device, the bar examination, that served as a reference point regarding the success or failure of its students and, by necessary implication, its educational programs. ${ }^{244}$ Such changes will nevertheless require a shift in focus that, I believe, presents law schools with both an obligation and an opportunity to undertake precisely the sorts of programs and studies I associate with the rigors of Grutter and Gratz.

In Part III-B, I examine key aspects of the social science research supporting the notion that diversity is a compelling constitutional interest. I focus on certain central elements of that research, identifying information and perspectives that can assist law schools as they intentionally structure their learning environments to enhance the likelihood that they are achieving the educational outcomes cited in Grutter and the new ABA

240. Grutter, 539 U.S. at 339.

241. See supra text accompanying notes $210-211$.

242. See infra text accompanying note 275 .

243. See infra text accompanying note 271 .

244. One persistent and sobering fact in the diversity debate has been the reality that "relatively large proportion of examinees of color, particularly black examinees ... failed the bar examination on the first attempt and did not make a second attempt." Linda F. Wightman, LSAC National Longitudinal Bar Passage Study 79 (1998). Both Richard Sander and his critics report similar findings. Sander is the author of a very controversial study suggesting that affirmative action may do more harm than good by admitting minority students to legal education programs for which they are ill-prepared and within which they struggle to succeed. Richard H. Sander, $A$ Systemic Analysis of Affirmative Action in American Law Schools, 57 STAN. L. REV. 367 (2004). Professors Ayres and Brooks have strongly criticized his work, but also note that "Sander's study ... highlights a real and serious problem: the average black law students's grades are startlingly low." Ian Ayres \& Richard Brooks, Does Affirmative Action Reduce the Number of Black Lawyers?, 57 STAN. L. REV. 1807, 1807 (2005). As Sander stresses, "[m]ost" scholars "concede (and none dispute) the basic facts . . . blacks are nearly two-and-one-half times more likely than whites not to graduate from law school, are four times more likely to fail the bar on their first attempt, and are six times more likely to fail after multiple attempts." Richard $\mathrm{H}$. Sander, A Reply to Critics, 57 STAN. L. REv. 1963, 1964-65 (2005). 
Standards. Finally, in Part III-C, I address the value of program assessment in law schools, a practice that has not heretofore been a cornerstone in legal education.

\section{A. Legal Education and Diversity: The Post-Grutter Realities}

Higher education's commitment to diversity is pervasive and longstanding. ${ }^{245}$ The American Association of University Professors was one of the early leaders attacking traditional policies and procedures, declaring in 1973 that, in its view, these "result in the exclusion of women and minorities from [academe] or their inclusion in only token proportions to their availability."246 More recently, sixty-two of North America's most prestigious universities responded to the threats posed by the Hopwood litigation and voter initiatives banning affirmative action with a statement emphasizing that "as educators ... [w]e believe that our students benefit significantly from education that takes place within a diverse setting."247 They declared that "[a] very substantial portion of our curriculum is enhanced by the discourse made possible by the heterogeneous backgrounds of our students." "248 And they asserted that "[i]f our institutional capacity to bring together a genuinely diverse group of students is removed - or severely reduced-then the quality and texture of the education we provide will be significantly diminished."249

Legal education has if anything been even more proactive than the rest of higher education in these matters. A broad spectrum of key actors in legal education filed briefs supporting the positions taken by the University of Michigan in the Grutter and Gratz litigation. These filings stressed both the moral and practical dimensions of legal education's commitment. For example, the primary "trade association" for legal education, the Association of American Law Schools, argued that "[r]ace-conscious admissions policies are necessary to achieve the paramount government objective of ensuring equal access to legal education, the legal profession, and the process of self-government." 250 A group of law deans echoed these sentiments, stressing "the harm to legal education, to the [law] schools as institutions, and to society" if race could not be considered in the admissions process. ${ }^{251}$ The Law School Admissions Council, which

245. See infra text accompanying note 78 .

246. AAUP Report, supra note 57, at 155.

247. Association of American Universities, On the Importance of Diversity in University Admissions, N.Y. TIMES, Apr. 24, 1997, at A17.

248. Id.

249. Id.

250. Brief of the Association of American Law Schools as Amicus Curiae Supporting Respondents at 3, Grutter v. Bollinger, 539 U.S. 306 (2003) (No. 02-241).

251. Brief of the American Law Deans Association as Amicus Curiae Supporting Respondents at 1, Grutter v. Bollinger, 539 U.S. 306 (2003) (No. 02-241). 
develops and administers the primary screening tool for law school admissions, the Law School Admissions Test, stressed its "strong interest in ensuring that standardized test scores are given the proper weight in the admissions process, and ... longstanding commitment to ensuring equal access to legal education for members of minority groups." 252 It then argued that " $[t]$ he inescapable lesson of the statistical evidence compiled year after year by LSAC is that unless America's law schools are allowed to adopt race-conscious admissions policies, many of the nation's lawyers will be trained in an environment of racial homogeneity that bears almost no relation to the world in which they will work, and in which all of us live." 253

The most telling arguments were arguably those made by the American Bar Association. It stressed that it "has worked to ensure that members of all racial and ethnic groups are represented in the legal profession." 254 It declared that "[f]ull participation in the legal profession by racial and ethnic minorities is a sine qua non for the effective functioning of the legal system and for the legitimacy of our system of government."255 And, echoing a reality documented by a number of other parties by the Court, ${ }^{256}$ it stressed that "[s]hould the Court proscribe these race-conscious admissions programs, the likely result will be a precipitous decline in the number of lawyers from under-represented racial and ethnic groups."257

These sentiments eventually became an accreditation reality. In August 2006, slightly over one year after Grutter and Gratz were decided, the ABA House of Delegates approved Standard 212(a), which states that all law schools "shall demonstrate by concrete action a commitment to providing full opportunities for the study of law and entry into the profession by members of underrepresented groups, particularly racial and

252. Brief of the Law School Admissions Council as Amicus Curiae Supporting Respondents at 2, Grutter v. Bollinger, 535 U.S. 306 (2003) (No. 02-241) [hereinafter LSAC Brief].

253. Id.

254. Brief of the American Bar Association as Amicus Curiae Supporting Respondents at 2, Grutter v. Bollinger, 539 U.S. 306 (2003) (No. 02-241) [hereinafter ABA Brief].

255. Id. at 8-9.

256. See, e.g., LSAC Brief, supra note 249 , at 3 ("The simple, demonstrable statistical fact is that most selective law schools in this country will have almost no students of certain races unless they adopt admissions policies designed to alter that outcome."); id. at 8-9 (indicating, for example, that "[f] or the fall 1997 entering class, the year petitioner applied to Michigan Law School, there were 3,447 applicants nationwide in" the statistical range threshold for admission to Michigan, only "17 of whom were black").

257. ABA Brief, supra note 254 , at 5. It is worth noting that the focus here seems to be on "representation" and "participation," rather than on the educational process itself. That is, the ABA argued largely for what I will describe as "structural" diversity. See infra text accompanying note 286. 
ethnic minorities, and a commitment to having a student body that is diverse with respect to gender, race, and ethnicity."258 Although the Interpretations of Standard 212 states that the Standard "does not specify the forms of concrete actions a law school must take," 259 the ABA does not appear to treat the pursuit of diversity as optional. It has made it quite clear that the mandate applies even in the face of "a constitutional provision or statute that purports to prohibit consideration of gender, race, ethnicity, or national origin in admissions or employment decisions." 260 And it has in fact insisted on substantial alterations in admissions practices as part of the accreditation process. ${ }^{261}$

The official explanation for the revision was that the prior standard, which spoke simply of the need for an "equal opportunity effort," 262 had "not been revised in 15 years [and] needed to be updated in the light of" Grutter and Gratz. ${ }^{263}$ Its exact meaning has, in turn, been disputed, ${ }^{264}$

258. AMERICAN BAR ASSOCIATION, 2008-09 STANDARDS FOR APPROVAl OF LAW SCHOOlS, Chapter 2: ORganization AND ADMINISTRATION, Standard 212(a) [hereinafter ABA STANDARDS], available at http://www.abanet.org/legaled/standards/standards.html. A parallel provision, Standard 212(b), imposes a similar requirement regarding the need to have "faculty and staff that are diverse with respect to gender, race, and ethnicity."

259. ABA STANDARDS, supra note 258, at Interpretation 212-13.

260. ABA STANDARDS, supra note 258, at Interpretation 212-1.

261. The most visible and controversial example of this is the case of the George Mason University Law School, which was criticized when "the site evaluation team for the ABA" discovered that "only $6.5 \%$ of the law school's entering students were minorities." Kenneth L. Marcus, The Right Frontier for Civil Rights Reform, 19 GEo. MASON U. CIV. RTS. L.J. 77, 109 (2008). In the wake of that finding, "the school was forced to implement significant racial preferences, despite its opposition to such practices." Id. See also Gail Heriot, Affirmative Action in American Law Schools, 17 J. Contemp. Legal Issues 237, 274-79 (2008) (discussing George Mason's experiences).

262. AMERICAN BAR ASSOCIATION, STANDARDS FOR APPROVAL OF LAW, Standard 211 , at 36-38.

263. Katherine S. Mangan, Bar Association Moves to Strengthen Diversity Requirements for Accreditation of Law Schools, Chron. Higher EdUC. DaILY NEwS, Feb. 12, 2006 (citing John Sebert, ABA Consultant on Legal Education), available at http://chronicle.com/daily/2006/02/200602140 ln.htm.

264. For example, Professor David Bernstein, who teaches at George Mason, argued that the revised standard meant that " $[\mathrm{r}]$ acial preferences will thus generally be necessary to comply" with the accreditation standards. David E. Bernstein, Affirmative Blackmail, WALL ST. J., Feb. 11, 2006, at A9. John Sebert, who was the ABA Consultant on Legal Education at the time the standards were revised, disagreed, declaring that Bernstein "got it completely wrong" and that "the revised standard clarifies that law schools may consider race and ethnicity in admissions . . . but does not require them to take that approach." Mangan, supra note 263 (quoting John Sebert). Sebert went on to state, however, that the net effect of Interpretation 212-2 was exactly what it said: "the mere fact that you may be in a state that has a statutorial provision prohibiting the consideration of race in the admissions process does not relieve you" of the obligation to enroll a diverse student body that has the traits mentioned in the standard. Id. 
prompting Dean Steven R. Smith, speaking as a representative of the ABA, to assail "misconceptions" about the nature and effect of the revisions in testimony before the United States Commission on Civil Rights. ${ }^{265}$ Nevertheless, the mandatory nature of the requirement seems clear: law schools shall demonstrate a commitment to affirmative action and diversity by taking concrete steps towards those ends. Moreover, while Dean Smith was arguably correct that "[t]he ABA is hardly unique in expecting the institutions it accredits to be committed to diversity," 266 the examples he lists of such requirements do not speak in such stark terms. The business college standard, for example, states simply that "[a]s a condition of eligibility to pursue business and accounting accreditation (and for maintenance of accreditation as well) the school must first define and support the concept of diversity appropriate to its culture, historical traditions, and legal and regulatory environment."267 The one that comes closest to the ABA approach, in turn, is in the standards for programs in Journalism and Mass Communications. ${ }^{268}$ Even here, however, the standards require simply that a program have a "written plan for achieving an inclusive curriculum, a diverse faculty and student population" 269 and "demonstrates effective efforts to help recruit and retain a student population eligible to enroll in institutions of higher education in the region or population it serves, with special attention to recruiting underrepresented groups." 270

265. Steven R. Smith, Opening Statement Before the United States Civil Rights Commission, at $84,87-89$, in U.S. COMMISSION ON CIVIL RIGHTS, AFFIRMATIVE ACTION IN AMERICAN LAW SCHOOLS: A BRIEFING REPORT (April 2007).

266. Id. at 87 .

267. Association to AdVANCE COLlegiate Schools of Business, Eligibility PROCEDURES AND ACCREDITATION STANDARDS FOR BUSINESS ACCREDITATION 13 (Revised, July 1, 2009), available at http://www.aacsb.edu/accredidation/BusinessStandards-2009-Final.pdf.

268. THE ACCREDITING COUNCIL ON EDUCATION IN JOURNALISM AND MASS COMMUNICATIONS, ACEJMC ACCREDITING STANDARDS (Sept. 2003), available at http://www2.ku.edu/ acejmc/PROGRAM/STANDARDS.SHTML.

269. Id. at Standard 3(a).

270. Id. at Standard 3(d). Dean Smith listed four other accrediting bodies, none of whose standards approximate those of the ABA. See COUNCIL OF THE AMERICAN LiBraRY ASSOCIATION, STANDARDS FOR ACCREDITATION OF MASTER'S PROGRAMS IN LIBRARY \& INFORMATION STUDIES 9 (Jan. 15, 2008) (Standard IV.1, "The school has policies to recruit and retain students who reflect the diversity of North America's communities."); LIAISON COMMITTEE ON MEDICAL EDUCATION, FUNCTIONS AND STRUCTURE OF a MEdiCal SCHOOL: STANDARDS For ACCREDITATION OF MEdiCAL EduCATION Programs Leading TO THE M.D. Degree 17 (June 2008) (Standard MS-8, "Each medical school must develop programs or partnerships aimed at broadening diversity among qualified applicants for medical school admission."); MIDDLE STATES COMMISSION ON HIGHER EDUCATION, CHARACTERISTICS OF EXCELLENCE IN HIGHER EDUCATION: REQUIREMENTS OF AFFILIATION AND STANDARDS FOR ACCREDITATION 3133 (Revised, March 2009) (Standard 8, Student Admissions and Retention, silent regarding diversity); id. at 37 (Standard 10, Faculty, stating "[f]aculty selection 
That said, the ABA approach is certainly consistent with the rhetoric that invariably accompanies discussions of diversity by the higher education establishment. In this respect, these standards seem to be suggestive harbingers of what the future likely holds. Higher education figures clearly believe that diversity is an essential element in educational excellence. It seems only logical then that these same individuals would expect accreditation standards and processes to take these beliefs into account.

It is also worth noting that the ABA is now moving from an "input" to an "outcomes" model for law school accreditation. ${ }^{271}$ Although the specific requirements that this will impose have not yet been determined, law schools will presumably be required in the future to prove through outcomes data that their graduates have indeed acquired both the theoretical knowledge and professional skills necessary to function as attorneys. This shift reveals a professional and educational commitment to assessing program outcomes "by the facts" or by the numbers. In the past, legal education was arguably subject to only a single quantitative measure of the actual success of its educational programs, the bar examination. A shift to an outcomes based accreditation model will likely add additional parameters. It would be remarkable if the $\mathrm{ABA}$, having made such an issue of diversity, did not also take the benefits associated with it into account in any outcomes-based approach. And, as law schools gear up to measure the outcomes of their educational programs, it would be remarkable if they did not also measure the educational benefits of their race-conscious admissions policies and practices, policies and practices that they have argued are central to their missions.

B. Institutional and Programmatic Considerations in Planning for a Diverse Learning Environment

As I indicated in Part I of this article, the Grutter majority relied heavily on "expert studies and reports entered into evidence at trial." 272 In particular, Justice O'Connor and her colleagues stressed that the applicable social science showed that the "benefits" of student body diversity are "substantial," leading to cross-racial understanding and to reductions in

processes should give appropriate consideration to the value of faculty diversity, consistent with institutional mission"); PLANNING ACCREDITATION BOARD, THE ACCREDItation DoCument: Criteria and Procedures OF the PlanNing ACCREDITATION Program 27 (Nov. 2006) (Standard 9.4, "The program shall document its progress in reaching its aspirations for the quantity, quality, and diversity of its student body.").

271. AMERICAN BAR ASSOCIATION, SECTION OF Legal EDUCATION AND ADMISSIONS TO THE BAR, REPORT OF THE OUTCOME MEASURES COMMITTEE 1 (July 27, 2008) ("T[his] report recommends that the Section re-examine the current ABA Accreditation Standards and reframe them, as needed, to reduce their reliance on input measures and instead adopt a greater and more overt reliance on outcome measures.").

272. Grutter v. Bollinger, 539 U.S. 306, 330 (2003). 
racial stereotypes, as well as enabling students to better understand persons of different races. ${ }^{273}$ They also declared that student body diversity "better prepares students for an increasingly diverse workforce and society, and better prepares them as professionals." 274

These findings are significant in and of themselves, as they provided the foundations for a holding that the student body diversity is a compelling constitutional interest. Their importance has in turn been amplified by the ABA, which modified its accreditation standards to take them into account, declaring in language which tracks closely to Justice O'Connor's opinion that "a law school shall take concrete actions to enroll a diverse student body that promotes cross-cultural understanding, helps break down racial and ethnic stereotypes, and enables students to better understand persons of different races, ethnic groups, and backgrounds." 275

The Court's use of social science materials as a basis for judicial decision-making has been and remains controversial. ${ }^{276}$ For example, some scholars have characterized this portion of the Grutter opinion as "secondary" and the use of social science evidence as "cautious." 277 There are good reasons to be careful. Considerable skill must be exercised, given both the methodological errors that can taint some social science research, ${ }^{278}$ and the need to make certain that the studies relied on are in fact generalizable to the environment at issue. ${ }^{279}$ That said, I believe that

273. Id.

274. Id.

275. ABA STANDARDS, supra note 258, at Interpretation 212-2 (emphasis added).

276. The literature discussing this is substantial and a full examination of the issues beyond the scope of this article. Two useful starting points for those wishing to review the history and arguments, pro and con, are Anne Richardson Oakes, From Pedagogical Sociology to Constitutional Adjudication: The Meaning of Desegregation in Social Science Research and Law, 14 MiCH. J. RACE \& L. 61 (2008), and Sanjay Mody, Note, Brown Footnote Eleven in Historical Context: Social Science and the Supreme Court's Quest for Legitimacy, 54. STAN. L. REV. 793 (2002).

277. Steven L. Willborn, Social Science in the Courts; The View from Michigan, in Social Consciousness in Legal DeCision MaKing: Psychological Perspectives 144 (Richard L. Wiener et al. eds., 2007).

278. A number of individuals, for example, have criticized the quality of the materials that Michigan relied on. See, e.g., James H. Kuklinski, Review: The Scientific Study of Campus Diversity and Students' Educational Outcomes, 70 PUB. OPINION Q. 1 (2006); Brian N. Lizotte, The Diversity Rationale: Unprovable, Uncompelling, 11 MiCH. J. RACE \& L. 625 (2005-06); Justin Pidot, Note, Intuition or Proof: The Social Science Justification for the Diversity Rationale in Grutter v. Bollinger and Gratz v. Bollinger, 59 STAN. L. REv. 761 (2006-07).

279. For example, most of the studies used by Michigan and its amici to bolster their case before the Court involved undergraduate education. See, e.g., Brief for Respondents at 22, Grutter v. Bollinger, 539 U.S. 306 (2003) (No. 02-241) (noting the "powerful and essentially uncontested evidentiary record in this case" and the expert reports filed at the district court level, which discussed only undergraduate education). The district court opinion in turn cited only the trial testimony of various administrators and faculty at the Law School, see Grutter v. Bollinger, 137 F. Supp. 2d 821, 833-36 
the critics of social science in the courts are wrong, both as a general matter, ${ }^{280}$ and specifically in the context of Grutter and Gratz. As I have argued and documented in this Article, social science materials helped inform Justice O'Connor's approach to these issues. More to the point, they can provide valuable assistance to law schools as they structure and assess their efforts to make the benefits they associate with diversity a reality for their students.

For example, the claim that a diverse learning environment can in fact influence actual educational outcomes has a strong basis in core social science research. I do not intend to explore those materials at length here. Instead, I simply note that it has long been a central tenet in developmental psychology that there are important post-childhood stages during which attitudes are influenced and values formed. For example, the pioneering work of Erik Erikson established that adolescents and young adults experience a number of important developmental stages, during which a sense of both personal and social identity is developed. ${ }^{281}$ One of the key experts in the Michigan litigation was Professor Patricia Y. Gurin. As she explained in the study she prepared for those cases, Erikson theorized that:

[I]dentity develops best when young people are given a psychosocial moratorium-a time and a place in which they can experiment with different social roles before making permanent commitments to an occupation, to intimate relationships, to social groups and communities, and to a philosophy of life. Ideally, the moratorium will involve confrontation with diversity and complexity, lest young people passively make commitments that follow their past, rather than being obliged to think and make decisions that fit their talents and feel authentic. ${ }^{282}$

The unique nature of legal education, furthermore, means that there is

(E.D. Mich. 2001), and a single social science study, the Gurin Report, see id. at 850 , which examined only undergraduate experiences. The perspectives offered by such materials are valuable and instructive. It remains to be seen, however, whether all of the conclusions drawn from the studies of undergraduate students apply equally to law students in a professional school setting.

280. I tend to agree with Judge Posner that in areas like this " $[t]$ he big problem is not lack of theory, but lack of knowledge-lack of the very knowledge that [social science] research, rather than the litigation process, is best designed to produce." Richard A. Posner, Against Constitutional Theory, 73 N.Y.U. L. REV. 1, 3 (1998) There are nevertheless good arguments on both sides of this debate that I do not have the time or space to explore in this article.

281. See Erik H. Erikson, Youth: Change and Challenge (1963); EriK H. ERIKSON, CHILDHOOD AND SOCIETY (2d ed. 1963); ERIK H. ERIKSON, IDENTITY AND THE LIFE CYCLE: SELECTED PAPERS (1959).

282. Expert Report of Patricia Gurin, in THE COMPELLING NEED FOR DIVERSITY IN Higher EDUCATION, at 101 (John A. Payton ed., 1999), reprinted in 5 MiCH. J. RACE \& L. 363 (1999) [hereinafter Gurin Report]. The Payton compilation was the original document prepared for the trial court. 
still room for the diversity imperative to operate. Marvin Peterson, for example, notes that professional schools have a particularly strong socializing influence on their students. ${ }^{283}$ Indeed, a number of commentators have emphasized the extraordinary psychological impact of law school on students. James Elkins describes the first year of law school as "a powerful, transformative experience in which the soul as well as the mind is at stake." 284 John Bonsignore agrees, arguing that within the first few months of attending law school, there is a "vigorous institutional effort to cut the individual loose from all ... psychological anchoring points."285 Law school, these individuals maintain, epitomizes a clash of competing cultures, creating a contest of wills between a student's values and the institution's values. The net effect, as described by Rand Jack and Dana Crowley Jack, is that "no one who attends law school for three years completely escapes the thorns that excise prior vision and implant new."286

This literature suggests that legal education's strong institutional culture may substantially influence student attitudes and beliefs, even after relatively brief exposure to the environment. More to the point, certain aspects of how legal education is provided may play an important role in influencing students' racial attitudes and beliefs. Paul Brest and Miranda Oshige maintain that "law students, like members of all segments of society, hold stereotypes, preconceptions, and prejudices based on group membership." 287 Thus, they argue, an institutional culture that embraces diversity and fosters "encounters among students from different backgrounds [will] tend to reduce prejudice and alienation."288

There are, however, two major problems that must be addressed. The first is that there may be some law schools whose administrators believe that the admissions decision is dispositive. This leads to an emphasis on "structural diversity," generally defined as the numerical representation of a critical mass of minority students. ${ }^{289}$ The underlying assumption at such

283. Marvin W. Peterson, ASHE Reader on Organization and Governance IN Higher EDUCATION (5th ed. 2000).

284. James R. Elkins, Rites of Passage: Law Students "Telling Their Lives," 35 J. LEGAL EDUC. 27, 28 (1985).

285. John J. Bonsignore, Law School: Caught in the Paradigmatic Squeeze, in BEFORE THE LAW, at 259 (John J. Bonsignore et al. eds., 3d. ed. 1984).

286. RAND JACK \& DANA CROWLEY JACK, MORAL VISION AND PROFESSIONAL DECISIONS: THE CHANGING VALUES OF WOMEN AND MEN LAWYERS 47 (1989). The "thorns" in question are those of the "bramble bush." See KARL N. Llewellyn, THE BRAMBLE BUSH: SOME LECTURES ON LAW AND ITS STUdY (1930).

287. Paul Brest \& Miranda Oshige, Affirmative Action for Whom?, 47 STAN. L. REV. 855, 863 (1995).

288. Id.

289. This is also called "representational diversity" or "numeric diversity." Even here, there are nuances. For example, "unitary" structural diversity simply measures the number of white students to the number of minority students. See Pidot, supra note 278 , at page 767 . "Heterogenic" diversity considers the number of different racial 
institutions is that structural diversity alone will provide "students with opportunities to interact with peers who are different from themselves and that these interactions ultimately contribute to a supportive campus environment and mediate students' intellectual and personal development." 290 This is arguably the focus of the current ABA accreditation standard, which addresses only the admissions process and decision and seems to assume that all of the benefits it embraces will inevitably follow. The ABA acknowledged when it undertook the recent revisions that this effort was undertaken in the light of the goals that diversity is presumed to achieve. ${ }^{291}$ But the segments of the current ABA standards actually dealing with the "Program of Legal Education" are silent in this regard, emphasizing simply the need for an "educational program that "prepares its students for admission to the bar, and effective and responsible participation in the legal profession." 292

Institutions and individuals who are content with simple structural diversity do not necessarily dispute the need for or value of "provid[ing] an environment in which students learn how to approach legal problems, as well as life itself, from multiple perspectives or viewpoints." 293 Rather, they suggest that structural diversity, "in and of itself," 294 is sufficient to meet their constitutional obligations. ${ }^{295}$ And they seem to believe that the educational goals that flow from diversity will be easily achieved "given the inevitable ways in which a critical mass of minority students will lead all students to confront and embrace alternative perspectives and viewpoints." 296

and ethnic groups represented in the student body. Id. Finally, "multifactored" diversity considers the race and ethnicity of individuals as well as other attributes including socioeconomic, geographic, and ideological considerations as well as a diversity of skills, interests, and experiences, including the demonstrated ability to overcome different kinds of disadvantages. See Kenneth L. Marcus, Diversity and Race-Neutrality, 103 Nw. L. REV. COLLOQUY 163, 164 (2008).

290. Gary R. Pike \& George D. Kuh, Relationships among Structural Diversity, Informal Peer Interactions and Perceptions of Campus Environment, $29 \mathrm{REV}$. HIGHER EDUC. 445, 426 (2006).

291. See supra text accompanying notes 255 and 260.

292. ABA STANDARDS, supra note 258, at Standard 301(a) (Objectives). Hopefully the revision process currently underway, which will result in a shift to an outcomesbased accreditation model, will take these matters into account.

293. Caminker, supra note 26, at 38.

294. Id. at 41. See also id. at 50 (noting that "Michigan Law School's admissions program passed constitutional muster despite the absence of proactive programming").

295. Id. at 40 (arguing that Grutter made structural diversity "sufficient" for constitutional purposes).

296. Id. at 41. It is not my intention here to pick on Dean Caminker and make him the spokesman for all legal education. That said, as Dean at Michigan, his statements are presumably accorded great weight in these matters, and I believe that individuals at that institution in particular should not convey the impression that structural diversity is sufficient. More importantly, Dean Caminker is not the only prominent spokesman 
Admitting a wide array of students is clearly an important first step. As one recent study notes, "[s]tructural diversity is perceived as a catalyst for promoting a more hospitable campus racial climate." 297 That same study stresses, however, that "[d]espite its importance" research has revealed "that the singular act of increasing the number of people of color on a campus will not create a more positive racial climate." 298 Structural diversity is accordingly "a necessary, but not sufficient, factor" if the goal is to actually create "a more comfortable and less hostile environment for all." 299

This perspective is not new. Patricia Gurin was one of the experts whose research Michigan supported and relied on as it fashioned its litigation strategy. ${ }^{300}$ She argues that "[i]f diversity is really going to mean anything, it is not just having students [of different races] in the same place. They have to interact. They need to learn to have deep and meaningful conversations about topics that people want to avoid."301 As she and her colleagues noted even before Grutter was decided, "[a]lthough structural diversity increases the probability that students will encounter others of diverse backgrounds, given the U.S. history of race relations, simply attending an ethnically diverse college does not guarantee that students will have the meaningful intergroup interactions that ... are important for the reduction of racial prejudice." 302 These interactions must, moreover, be conducted with care, as simply "[t]alking about these topics can blow up if you don't do it right." 303

The single most important consideration for all institutions, and in particular for law schools, is then to understand that it is not enough to simply admit a diverse class. The constitutional expectation in the wake of Grutter and Gratz is that the benefits associated with diversity will be real,

with Michigan connections to speak in this vein. See, e.g., Bollinger, supra note 28, at 1591 (describing the goal of diversity as "help[ing] students expand their capacities to imagine other ways of experiencing life and of seeing the world" and stating that "being around people who are in some ways different from you, or whom you perceive to be different, is one of many ways of developing this mentality").

297. Sylvia Hurtado et al., Assessing the Value of Climate Assessments: Progress and Future Directions, 1 J. Diversity HIGHER EDUC. 204, 207 (2008).

298. Id.

299. Id. See also Jiali Luo \& David Jamieson-Drake, A Retrospective Assessment of the Educational Benefits of Interaction Across Racial Boundaries, 50 J. COLL. STUD. DEV. 67, 84 (2009) ("Structural diversity is only the first step in a journey of a thousand miles to capitalize on the educational value of multicultural diversity.").

300. See supra text accompanying notes 279 and 282.

301. Peter Schmidt, 'Intergroup Dialogue' Promoted as Using Racial Tension to Teach, Chron. HIGHER EDUC. DAILY NEwS, July 16, 2008, available at http://chronicle.com/daily/2008/07/3829n.htm.

302. Patricia Gurin et al., Diversity and Higher Education: Theory and Impact of Educational Outcomes, 72 HARV. EDUC. REV. 330, 331 (2002).

303. Schmidt, supra note 301 (quoting Patricia Gurin). 
that is, that they will actually occur. The educational policy expectation in turn is that there will be proactive programming. The clear consensus on the part of the experts in the field of measuring the educational benefits of student body diversity is that structural diversity is a necessary but not sufficient condition to achieve the educational benefits that institutions presumably seek when they consciously fashion a diverse student body. ${ }^{304}$ Rather, "substantial and meaningful interaction" between different racial and ethnic groups is central to the "development of democratic sensibilities" 305 that is the professed objective of diversity. Moreover, developmental theories indicate that social interaction is necessary to elicit the cognitive disequilibria that spur growth and development in students. ${ }^{306}$

This is why I noted at the outset of this Article that the manner in which the Court proceeded in Grutter and Gratz made those cases a "good newsbad news" scenario for higher education in general and legal education in particular. Higher education in general, and legal education in particular, are arguably committed to diversity because educators believe that it will have a positive educational impact on its students. If that is indeed the case then law schools must take positive steps to see that there is substantial and meaningful interaction between students of different racial and ethnic groups. At the risk of repetition, these sorts of contacts are the keys to student socio-cognitive growth.

Diversity research builds "on the theory and research of developmental and cognitive psychologists" who have found that "discontinuity" is necessary to encourage "more active thinking processes among students, moving them from their own embedded worldviews to consider those of another (or those of their diverse peers)."307 Dissonance "occurs when

304. See, e.g., AleXAnder Astin, What Matters in COllege? Four Critical YEARS REvisITED 362 (1997); Nida Denson \& Mitchell J. Chang, Racial Diversity Matters: The Impact of Diversity-Related Student Engagement and Institutional Context, 46 AM. EDUC. RES. J. 322, 324 (2009) (a diverse environment is primarily important as it increases the chances that students will engage in more frequent crossrace interaction); Hurtado, Linking Diversity, supra note 149, at 190 ("[I]t is clear that enhancing the structural diversity of a student body is a necessary but not sufficient condition to produce these outcomes.").

305. Hurtado, Linking Diversity, supra note 149, at 190 . See also Lisa B. Spanierman et al., Participation in Formal and Informal Campus Diversity Experiences: Effects on Students' Racial Democratic Beliefs, 1 J. DIVERSITY HighER EDUC. 108, 124 (2008) ("[P]articipation in formal campus experiences is important for White, Black, and Latino students in predicting critical awareness of racial issues and diversity appreciation.").

306. See ARTHUR W. CHICKERING \& LINDA REISSER, EdUCATION AND IDENTITY (Jossey-Bass 2d ed. 1993); Rolf E. H. MuUSS, THEORIES OF ADOLESCENCE (Random House 5th ed. 1988); WILLIAM GRAVES PERRY, FORMS OF INTELLECTUAL AND ETHICAL DEVElopMENT IN THE COLlege YeARS: A SCHEME (Holt Rinehart \& Winston 1970); and Jean Piaget, The Equilibration of Cognitive Structures: The Central PROBLEM OF INTELLECTUAL DEVELOPMENT (1985).

307. Hurtado, Linking Diversity, supra note 149, at 189. 
students encounter unfamiliar and novel situations, people, and experiences and they cannot continue to rely on familiar ways of thinking and acting." 308 The sorts of learning and individual growth associated with diversity take place when individuals recognize cognitive conflicts or contradictions. ${ }^{309}$ These encounters "may lead to a state of uncertainty, instability, and anxiety. ${ }^{310}$ However, "with the right amount of support and challenge, these moments of instability can lead to many dimensions of growth." 311

There are a number of ways in which law schools can facilitate the sorts of encounters that I have described here. The most obvious and most frequently discussed is through the content and process of classroom instruction. Much of the attention in the post-Grutter literature has focused on this. Professor Brown, for example, has argued that Critical Race Theory should be an integral aspect of instruction across the curriculum. ${ }^{312}$ Professor Chambers-Goodman has suggested a number of ways in which classroom instruction can be shaped to maximize the potential benefits of diversity. ${ }^{313}$ And Professor Bruckner has touted the value of cooperative learning, arguing in particular that this approach best takes into account critical differences in the cultures and learning styles of diverse groups. ${ }^{314}$ In each instance, however, the argument is, as it should be, that the positive outcomes sought are best pursued as a matter of conscious planning and course design, rather than happenstance.

For example, both positive institutional support of cross-race student interaction $^{315}$ and directed intergroup dialogues ${ }^{316}$ have been found to

308. Id. See also Gurin Report, supra note 282, appendices available at http:www.vpcomm.umich.edu/admissions/legal/expert/gurinapd.html. Gurin discusses evidence about automatic thinking can be challenged by "discontinuity" and "incongruity" that can lead students to more sophisticated thinking. Id. at 369-70.

309. Hurtado, Linking Diversity, supra note 149, at 190.

310. Id.

311. Id.

312. See Brown, supra note 25, at 27-34. See also Carla D. Pratt, Taking Diversity Seriously: Affirmative Action and the Democratic Role of Law Schools: A Response to Professor Brown, 43 Hous. L. REV. 55 (2006).

313. Chris Chambers-Goodman, Retaining Diversity in the Classroom: Strategies for Maximizing the Benefits that Flow from a Diverse Student Body, 35 PEPP. L. REV. $663(2008)$.

314. Carole J. Buckner, Realizing Grutter v. Bollinger's “Compelling Educational Benefits of Diversity"-Transforming Aspirational Rhetoric into Experience, 72 U.M.K.C. L. REV. 877 (2004).

315. See, e.g., Mitchell J. Chang et al., Cross-racial Interaction Among Undergraduates: Some Consequences, Causes, and Patterns, 45 RES. HIGHER EDUC. 529 (2004); Nisha C. Gottfredson et al., The Effects of Educational Diversity in a National Sample of Law Students: Fitting Multilevel Latent Variable Models in Data with Categorical Indicators, 44 MULTIVARIATE BEHAV. Res. 305, 319 (2009); Somnath Saha et al., Student Body Racial and Ethnic Composition and Diversity-Related Outcomes in U.S. Medical Schools, 300 J. AM. MED. ASS'N 1135, 1139 (2009); Patrick 
provide the necessary "cognitive dissonance" that has been shown to promote the broad-based set of socio-cognitive skills, democratic values, and enhanced complex thinking skills noted in both Grutter and the ABA Standards. Structured intergroup dialogues in particular provide "opportunities for facilitated, extended discussions about diversity" 317 and are associated with increases in students' perspective-taking skills. ${ }^{318}$ This pedagogical technique could be used in the classroom setting to help equip students with the tools for engaging in civil discourse about difficult social issues. $^{319}$ Indeed, virtually any technique that calls attention to the interaction between law and racial or ethnic status could be utilized in one or more courses, providing parameters for targeted discussion to probe social dimensions of law and policy that might otherwise go unnoticed. ${ }^{320}$ The research stresses, however, that success is almost invariably associated with active institutional involvement.

It is also critical to understand that both positive and negative effects may occur from increased diversity. ${ }^{321}$ For example, Professor Sylvia Hurtado, a nationally known scholar and past president of the Association for the Study of Higher Education (ASHE), recently noted that "students who reported positive, informal interactions with diverse peers had higher scores on measures of more complex thinking about people and their behavior, cultural awareness, and perspective-taking skills (i.e., the ability to see the world from someone else's perspective)." 322 In contrast, "students who had negative interactions with diverse peers (conflict or hostility) were not only least skilled in intergroup relations but also demonstrated lower scores on the outcomes, indicating that they were also least likely to develop the habits of mind to function in a diverse and global

J. Terenzini et al., Racial and Ethnic Diversity in the Classroom: Does It Promote Student Learning?, 72 J. HiGHER EDUC. 509 (2001).

316. See, e.g., Intergroup Dialogue: Deliberative Democracy IN School, COllege, COMMUNITY, AND WORKPlaCe (David Schoem \& Sylvia Hurtado, eds., 2001); Anthony Lising Antonio et al., Effects of Racial Diversity on Complex Thinking in College Students, 15 PsYCHOL. Scl. 507 (2004); Schmidt, supra note 301 (discussing the Gurin intergroup dialogue project).

317. Hurtado, Linking Diversity, supra note 149, at 192. See also Schoem \& Hurtado, supra note 316.

318. Id. See also Victor B. Saenz et al., Factors Influencing Positive Interactions Across Race for African American, Asian American, Latino and White College Students, 48 RES. HIGHER EDUC. 1 (2007).

319. Hurtado, Linking Diversity, supra note 149, at 192. See also Schoem \& Hurtado, supra note 313.

320. See, e.g., Brown, supra note 24; Rebecca Tsosie, Engaging the Spirit of Racial Healing within Critical Race Theory: An Exercise in Transformative Thought, 11 MICH. J. RACE \& L. 21 (2005).

321. Denson \& Chang, supra note 304 , at 324.

322. Hurtado, Linking Diversity, supra note 149, at 191. 
world." 323 Positive student interactions, embraced and supported by key institutional constructs, are then crucial to achieving positive, as opposed to negative, learning outcomes.

Two recent studies involving professional-level students are instructive. The first involved a national sample of law students and found that "racial diversity increases intergroup contact" and "that intergroup contact increases perceived diversity of ideas" and "decreases prejudiced attitudes." 324 The authors note that "the perceived openness of the intellectual atmosphere" is key to the reduction in prejudiced attitudes." 325 These results are consistent with one of the central tenets in developmental psychology, the "the contact theory," which posits that positive attitude change among group members is most likely to be achieved when there are institutional supports in place that foster and embrace such cognitive and attitudinal change. ${ }^{326}$

A second study surveyed over 20,000 graduates from 118 allopathic medical schools in the United States and found, after adjusting for student and school characteristics, that white students who attended the most diverse schools had greater odds of high self-rated cultural competence compared with students at schools with less racial diversity. ${ }^{327}$ In addition, white students in the high diversity schools also had higher odds of having strong attitudes endorsing equitable access to care compared with those in the lowest diversity schools. 328 Further, the authors found a "significant interaction between school institutional climate" and white students' selfrated cultural competence. ${ }^{329}$ Specifically, the presence of a higher proportion of underrepresented racial minority students "was associated with higher self-rated cultural competence among white students when the institutional climate was perceived to be more positive." 330

These studies suggest the types of programming that might be undertaken. I cannot at this time offer a specific curricular and institutional plan for law schools to follow to ensure that educational benefits of racial diversity are occurring at their institutions. Indeed, I shouldn't: one of the most important considerations is that diversity efforts match institutional mission, a key dynamic that will vary from institution to institution. I can emphasize that the relevant social science studies do tell us that students must be able to interact with students of other races in a variety of ways. Sometimes the topics will be specifically related to race. In other instances

323. Id.

324. Gottfredson et al., supra note 315 , at 319.

325. Id.

326. Id. See also Gordon D. Allport, The Nature of Prejudice (1954).

327. Saha et al., supra note 315 , at 1139.

328. Id.

329. Id. at 1140

330. Id. 
they will not. The one constant, however, is that these interactions take place in a positive and supportive institutional environment. This requires a significant amount of intentional institutional effort, and it is important for law schools to recognize and act on this reality.

To their credit, many key figures in legal education seem to recognize this. Dean Caminker, for example, acknowledges the existence, and "critical importance" of this "second-generation question," conceding that "[t]here is a meaningful distinction between simply creating a diverse community and actually getting the community to function so as to achieve the goals of diversity." 331 He then dilutes the force of that concession by arguing that structural diversity is all that Grutter and Gratz require. ${ }^{332}$ I disagree. I see in those opinions the expectation that law schools will undertake the programming necessary to achieve their professed goals. Even were that not the case, I see such activities as the only educationally responsible way in which to proceed.

I do agree with Dean Caminker that the problems associated with this "second phase" are likely to prove "vexing." 333 Professor Gurin's observations about both the risks and rewards inherent in diversity programming are telling. ${ }^{334}$ Such programming is, nevertheless, the necessary next step for law schools if they are to achieve anything more than what has appropriately been characterized as "classroom aesthetics" 335 and "viewbook diversity." 336

\section{Assessment and the True Commitment to Diversity}

Without assessment, the rhetoric extolling the centrality of raceconscious admissions plans rings hollow. As noted above, ${ }^{337}$ social science provides us with some basic considerations for structuring the educational experiences to support the important learning outcomes linked to racial diversity. In particular, these studies reveal that diversity may have no effect, or even negative effects, on learning outcomes if careful attention is not paid to the nature of cross-race student interaction and dialogue. ${ }^{338}$ If institutions using race-based admissions policies truly are committed to achieving the outcomes that they assert are related to diversity, then they must create and carry out an assessment plan that will measure whether

331. Caminker, supra note 26 , at 38 .

332. See supra text accompanying note $290-96$.

333. Caminker, supra note 26 , at 38 .

334. See supra text accompanying notes $300-03$.

335. See Grutter, 539 U.S. at 355 (Thomas, J., concurring and dissenting).

336. See Scott Jaschik, Viewbook Diversity vs. Real Diversity, INSIDE HIGHER EDuC., July 2, 2008, available at http://www.insidehighered.com/news/2008/07/02/viewbooks.

337. See supra text accompanying notes 273-277.

338. See supra text accompanying notes 309-320. 
these outcomes are indeed occurring. More to the point, they must make certain that they have the information necessary to assist them in the event that find it necessary to re-examine their institutional climate and programs and move toward actually achieving these outcomes if they are not already occurring.

The ultimate goal of an outcomes-based assessment scheme is to measure learning outcomes and to use the results of the assessment to plan improvements and make recommendations for future action consistent with the findings of the study. ${ }^{339}$ There a number of steps in any sound academic assessment plan, including: articulating the institution's or program's "mission"; based on that mission, specifying the intended results of discrete academic programs or practices; purposefully planning curricular or institutional points of access so that those results (or outcomes) can be achieved; implementing methods to systematically identify whether the end results have been achieved; and finally, using the results to plan improvements in the programs or practices that will create enhanced opportunities for these outcomes to occur. ${ }^{340}$

Both Grutter and the ABA Standards articulate the key outcomes that should be associated with race-conscious diversity initiatives at law schools. ${ }^{341}$ Again, at the risk of repetition, these include: promoting crossracial understanding; breaking down racial stereotypes; enabling students to better understand persons of different races; promoting better classroom discussion; better preparing students for an increasingly diverse workforce and society; better preparing students to become professionals; and finally, providing pathways to positions of leadership in society. Depending on the school's mission, an individual law school might choose somewhat different outcomes or articulate them in a different manner. Either way, a truly narrowly tailored diversity plan must stress the development and identification of the curricular and institutional processes by which students can make progress along the articulated learning dimensions.

Assuming an institution adopts the learning outcomes noted by Grutter and embraced by the $\mathrm{ABA}$, it might include a range of curricular interventions. For example, it could incorporate at least one targeted racial awareness dialogue in an established orientation program for first year students, and follow that with requiring student participation in a course that utilizes Critical Race Theory, or any other related technique, in the analysis of substantive law. If institutions do not have such targeted and institutionally supported opportunities for students to benefit from racial diversity, such curricular interventions and institutional climate issues must

339. MarileE J. Bresclani, OUTCOMES-Based ACADEMIC AND CO-CuRricular PROGRAM REVIEW: A COMPILATION OF INSTITUTIONAL GOOD PRACTICES 14 (2006).

340. Id.

341. See supra text accompanying notes 265-272. 
be developed and addressed.

Thereafter, an assessment plan must be created and implemented. The key here is to understand that the assessments must be longitudinal. ${ }^{342}$ That is, meaningful data must be collected both before and after exposure to the diversity experience in order to determine whether the experience itself produced the learning outcomes. Careful attention must also be paid to the means of testing for the required outcomes. For example, a survey that simply asks the students just prior to graduation to "self assess" whether they are "more open to people of another race" or "whether they are less prejudiced now than when they entered law school" is replete with methodological errors. ${ }^{343}$ Rather, the institution must develop methods of testing whether the learning outcomes were achieved without the responses being subject to "social desirability" effects. Affirmative action and diversity are controversial and contentious subjects. Studies that probe those topics directly run into concern with respondents who give a "socially desirable" answer rather than a "true" answer. As Maria Krysan notes, "self-reports of any socially sensitive topic, including race, are subject to social desirability pressures." 344 Individuals wish "to be and appear to be good people." 345 This is sometimes problematic in an environment where institutional leaders create the impression that opposition to affirmative action or diversity runs the risk of being labeled, for example, as "telling the world, "Women and minorities need not apply.",346

342. That is, there must be some basis for comparison, as basic social science principles instruct that "[c]omparisons need to be made between students who experience different types of education. The term comparison should be stressed because survey research done on a single group often leads to invalid conclusions about cause-and-effect relationships." BRUCE W. TUCKMAN, CONDUCTING EDUCATIONAL RESEARCH 235 (4th ed. 1994).

343. See, e.g., id. ("The more transparent or obvious the purpose of a questionnaire, the more likely respondents are to provide the answers they want others to hear about themselves rather than the ones that may be true."). See generally EDWARD L. VOCKell \& J. William Asher, EduCATIONAl ResearCh (2d ed. 1995).

344. Maria Krysan, Prejudice, Politics, and Public Opinion: Understanding the Sources of Racial Policy Attitudes, 26 ANN. REV. SOC. 135, 138 (2000).

345. Seymour Sudman \& Norman H. Bradburn, Asking Questions: A PRACTICAL GUIDE TO QUESTIONNAIRE DESIGN 6 (1982).

346. Mary Sue Coleman, Oppose Prop 2; affirmative action helps economy, LANSING ST. J., Sept. 24, 2006, available at http://www.diversity.umich.edu/research/msc-editorial.php. Such rhetoric is, unfortunately, coin of the realm for both supporters and opponents of affirmative action and diversity. Compare Thomas C. Wilson, Whites' Opposition to Affirmative Action: Rejection of Group-based Preferences as well as Rejection of Blacks, 85 SOC. FORCES 111,111 (2006) ("Research clearly shows that whites' opposition to race-based preferences is motivated by 'new, but not old-fashioned' racism.'), and Deirdre M. Bowen, Brilliant Disguise: An Empirical Analysis of a Social Experiment Banning Affirmative Action, IND. L.J. (characterizing opposition to affirmative action as the feelings of "Whites who felt displaced from their throne of entitlement [and] began to push back") (forthcoming 2010), with Paul Craig Roberts \& Lawrence M. Stratton, Jr., 
Further, law schools should collect a range of data from incoming students, assess again after each year of law school, and then collect data upon graduation. The information should be detailed and wide-ranging. In addition to basic background characteristics, the law school should gather attitudinal data on entry to law school, including attitudes that might be subject to change based on the various programming efforts undertaken, for example, in-depth intergroup dialogues, or the use targeted instruction techniques in the classroom. It should then measure the same attitudes again at the end of law school. A supplemental approach is to use a series of vignettes that are stacked with a range of issues for the students to identify and discuss. So, for example, analysis of such vignettes might show a marked sophistication in student analysis of those scenarios by displaying a greater level of critical thinking and the reduction in the use of racial stereotypes. Students might also offer a more nuanced solution to a problem-involving scenario, such as a client interview, that requires students to draw upon cross-cultural experiences and knowledge. Data documenting such positive changes would provide solid information to show that the learning outcomes are being achieved. Finally, since some of the outcomes, such an improved ability to work in a diverse setting, suggest they might be achieved after graduation, data collection should continue at regular intervals post-graduation.

When the data is collected and analyzed, the schools can use it to target strengths and weaknesses in the law school experience. As part of this process law schools should seek assistance from internal sources who have program assessment or statistical experience and/or they should call upon campus or community resources to assist them in this process. This process might not be easy, but a program of outcomes assessment will underscore a true commitment to diversity for those institutions using race as a factor in admissions decisions.

\section{IV.CONCLUSION}

One of the true ironies in the debate about affirmative action and diversity is the deep disconnect that exists between higher education's embrace of diversity and the general public's seeming lack of support for it, especially if achieving diversity involves the use of race-related preferences. Higher education has always led the way in what Justice Blackmun characterized as the need for "first taking race into account." 347

Color Code, NAT'L REV., Mar. 20, 1995, at 36 (characterizing affirmative action as "reverse discrimination [that] violates fundamental norms of fair play"), and David G. Rosenbaum, Files From 80's Lay Out Stance of Bush Nominee, N.Y. TIMES, July 27, 2005 , at Al (quoting a 1981 report written by now Chief Justice John G. Roberts, Jr., to the effect that "the 'obvious reason' affirmative action programs had failed was that they 'required the recruiting of inadequately prepared candidates."').

347. Regents of the Univ. of Cal. v. Bakke, 438 U.S. 265, 407 (1978) (opinion of 
The commitment on the part of legal education is, if anything, even more pronounced given the decision to mandate the pursuit of diversity as part of the accreditation process. ${ }^{348}$ The general public, however, does not seem to share these convictions. In May 2009, for example, the Pew Research Center released the results of polling data that found that while "public ... support of the principle of equal opportunity for all" remains high, ${ }^{349}$ only $31 \%$ of the public supported minority preferences and $65 \%$ of them opposed them. ${ }^{350}$ These data reflect consistent realities in recent years: public support for racial preferences is comparatively low, and the opponents of such preferences have had near complete success at the polls when they place ballot measures banning affirmative action before the voting public. ${ }^{351}$

The University of Michigan's own experiences in the wake of Grutter and Gratz are instructive in this regard. Slightly over one year after the decisions were handed down the people of the state of Michigan approved a ballot initiative amending the state constitution, declaring that " $[\mathrm{t}] \mathrm{he}$ University of Michigan ... shall not discriminate against, or grant preferential treatment to, any individual or group on the basis of race, sex, color, ethnicity, or national origin." 352 The measure was styled as the Michigan Civil Rights Initiative and was championed by, among others, Jennifer Gratz, the named plaintiff in the case challenging the

Blackmun, J.).

348. See supra text accompanying notes $255-258$.

349. Pew Research Center for the People \& the Press, Trends in Political VALUES AND CORE ATTIDTUdES: 1987-2009 at 56 (May 21, 2009), available at http://people-press.org/reports/pdf/517.pdf (noting that "[n]early nine-in-ten (87\%) agree that: 'Our society should do what is necessary to make sure that everyone has an equal opportunity to succeed"').

350. Id. The report notes that the trend since 1987 has been fairly constant, with support increasing slightly, from $24 \%$ to $31 \%$, while opposition has declined slightly, from $71 \%$ to $65 \%$. Id.

351. See supra text accompanying notes 115-118 (discussing the ballot measures and votes in California and Washington). The only state-wide measure to be defeated was the one on the Colorado ballot during the general election in November, 2008, which failed by a narrow margin. The defeat was a setback for the anti-affirmative action movement, but may also have been a product of the unique dynamics created by the Obama campaign's substantial efforts to win the state. See Reeves Wiedman, Colorado's Singular 'No', CHRON. Higher EduC., Nov. 21, 2008, at A4 ('Supporters of affirmative action have finally found a way to defeat state ballot measures that would ban such programs: Latch onto an inspirational presidential candidate with piles of cash and an unprecedented voter-turnout machine."). In Nebraska, a state in which candidate Obama "never set foot . . . after the primary season," $i d$. , a "nearly identical" measure "passed easily with nearly 58 percent of the vote." Dan Frosch, Vote Results Are Mixed On a Ban On Preference, N.Y. TiMES, Nov. 8, 2008, at A19.

352. MICH. CONST. art. I, $\S 26$, cl. 1. For a detailed history of the referendum from the point of view of those supporting it, see CAROL M. ALLEN, ENDING RaCIAL PREFERENCES: THE MiCHIGAN STORY (2008). 
undergraduate admissions program invalidated by the Court. ${ }^{353}$

The University fought the measure tooth and nail. It became an active member of One Michigan United, a broad, well-funded coalition that vigorously opposed passage of the proposition. ${ }^{354}$ In an editorial statement, President Mary Sue Coleman declared that "our state stands on the brink of telling the world, "Women and minorities need not apply.",355 And she made largely the same case the University had pressed before the Court three years earlier: "Affirmative action works; it is a targeted, not heavyhanded, tool. Impressive social science research demonstrates the positive educational outcomes linked with diverse classrooms. Students learn better in a diverse class. They are more open to different perspectives, and are better prepared to participate in a global economy." 356 Her pleas fell on deaf ears. The measure was approved by substantial majority of those voting, ${ }^{357}$ in what one of its proponents called a "dramatic victory" in a "very tough state." 358 It then survived a series of legal challenges questioning both the manner in which the measure was placed on the ballot ${ }^{359}$ and its constitutionality. ${ }^{360}$

Colleges and universities do not function in a vacuum. They exist, and are valued and valuable, precisely because they serve the needs and interests of the communities that support them. This is especially true for public colleges and universities, which depend on public financing. It is

353. See Peter Schmidt, A Referendum on Race Preferences Divides Michigan, CHRON. Higher EdUC., Oct. 27, 2006, at A21 ("Jennifer Gratz is at it again . . . trying to accomplish at the polls what she could not in the courts.").

354. See Tamar Lewin, Campaign to End Race Preferences Splits Michigan, N. Y. TimEs, Oct. 31, 2006, at Al (noting that One United Michigan had "raised and spent $\$ 3.3$ million"). The Law School Admission Council, which oversees the development and administration of the LSAT, was also an active opponent of the measure. See Schmidt, supra note 350 , at A23 (noting that LSAC donated $\$ 250,000$ to One United Michigan).

355. Coleman, supra note 343.

356. Id.

357. See Coalition to Defend Affirmative Action v. Regents of the Univ. of Mich., 529 F. Supp. 2d 924, 931 (E.D. Mich. 2008) (noting that the final margin was $57.9 \%$ for and $43.1 \%$ against and that "[o]nly three of Michigan's 83 counties rejected the measure").

358. Peter Schmidt, Michigan Overwhelmingly Adopts Ban on Affirmative-Action Preferences, CHRON. HighER EDUC., Nov. 17, 2006, at A23 (quoting Ward Connerly). Connerly is a former regent of the University of California and has been one of the major forces behind the passage these measures, in particular Proposition 209 in California. See Lewin, supra note 351, at A20.

359. See Operation King's Dream v. Connerly, 501 F.3d 584, 589 (6th Cir. 2007) (noting that the district court in this action found "widespread fraud" on the part of individuals securing signatures to place the measure on the ballot). The court ultimately held that the passage of the measure rendered claims related to this moot. Id. at 592 .

360. See Coalition to Defend Affirmative Action, 529 F. Supp. 2d at 294 (rejecting the constitutional challenges). 
also a special concern for law schools, whose core mission is to provide well-trained professionals, able and willing to provide the sorts of legal services required by their communities. The challenges posed by public opposition to affirmative action and diversity are accordingly significant.

Both scholars ${ }^{361}$ and individual members of the Court ${ }^{362}$ have suggested that race-conscious admissions plans are likely to remain targets of further litigation. The public interest law firms that pursue such lawsuits have in turn made it quite clear that they are ready, willing, and able to bring such actions. ${ }^{363}$ Now is not the time for diversity's champions to rest on their laurels. New challenges to affirmative action and diversity are inevitable and will almost certainly be more sophisticated than those mounted in the past. In particular, guided by the Court, sophisticated plaintiffs are likely to attack many of the basic assumptions that inform the case for diversity ${ }^{364}$ and, in particular, the extent to which a given affirmative action plan comports with the true rigors of the Grutter analysis. Michigan was in certain respects fortunate, as the plaintiffs in Grutter and Gratz conceded the point that diversity could have positive educational outcomes. The few attacks on that point made in those cases were too little and came too late. ${ }^{365}$ Future defendants may not be so fortunate. ${ }^{366}$

361. See, e.g., Evan Caminker, A Glimpse Behind and Beyond Grutter, 48 ST. Louls U. L.J. 889, 896 (2004) ("Justices Scalia and Thomas . . basically $\operatorname{tr}$ [ied] to foment, in their separate opinions, further litigation.").

362. See, e.g., Grutter v. Bollinger, 539 U.S. 306, 348 (Scalia, J., concurring and dissenting) ("[T]oday's Grutter-Gratz split doubleheader seems perversely designed to prolong the controversy and the litigation.").

363. See, e.g., CIR Press Release, supra note 9 ("Although the court upheld the law school system, this too, will end up as cold comfort for Michigan and schools with similar practices. Anything they do will likely be a smokescreen for quotas-and that just puts us back in litigation."). See also Scott Jaschik, Is Affirmative Action in Decline or Out of Control?, INSIDE HIGHER EDUC., Oct. 9, 2008, available at http://www.insidehighered.com/news/2008/10/09/affirm (discussing the Fall 2008 ballot initiatives and noting CEO's extensive studies challenging various affirmative action policies).

364. For example, Roger Clegg, the President and General Counsel of the Center for Equal Opportunity, has stressed that "[l]ike generals, lawyers often err by preparing to fight the just-past war rather than the next one . . ." Roger Clegg, Attacking "Diversity": A Review of Peter Wood's Diversity: The Invention of a Concept, 31 J. C. \& U. L. 417, 425 (2005). He suggests six arguments that should be made in future litigation, the first of which is to "[a]ttack the social science evidence that diversity provides "educational benefits." Id.

365. See, e.g., Brief for National Association of Scholars as Amicus Curiae Supporting Petitioners at 18-21, Grutter v. Bollinger, 539 U.S. 306 (2003) (No. $02-$ 241) (citing a single study that showed that the "fostering of group over individual identity by universities has led to more, not less racial balkanization on our nation's campuses").

366. In one such lawsuit working its way through the federal courts, a challenge to the system now employed by the University of Texas, the plaintiffs to date do not appear to have read Clegg, see supra note 361, or to have learned from past litigation 
The ability to successfully resist future sallies may well depend on the extent to which individual institutions live up to the new realities posed by what Justice O'Connor and her colleagues actually did when they gave Bakke its teeth. Serious, good-faith programming tailored to the actual institutional mission is essential. So is ongoing, comprehensive assessment. Both of these will provide valuable support in the face of future litigation. They will also offer a means to persuade an otherwise skeptical public that racially-defined admissions preferences serve important social interests. Public support for race-based affirmative action measures is essential, and institutions should seize the opportunity they now have to develop and make available information demonstrating that their assumptions about the benefits of a diverse learning environment are now supported by compelling educational facts.

As Professor Hurtado has argued, "[w]hile [Grutter and Gratz have] allowed institutions to better articulate how diversity can ideally work in an educational setting, it is important for campuses to consider how diversity initiatives are central to their key mission in practice." 367 Once again, Professor Hurtado eloquently expressed the challenge when she observes that "[t]he institutions that take the least transformative approach to educating diverse students risk criticism and attack when diversity initiatives are considered 'add ons' or marginal to the institutional functioning." 368

Our nation's colleges and universities now have the opportunity to show a true commitment to diversity, not because it offers political or social cover, but because of the educational benefits it arguably confers. It would be unfortunate, at best, if institutions with race-conscious admissions programs-programs that may well be achieving their intended goals-are challenged to produce evidence to that effect, and are unable to do so because they have failed to recognize both the opportunities and challenges offered by Grutter and Gratz. Bakke now has teeth. It is time to recognize this and act accordingly. That is the best possible defense in future litigation and the surest route for gaining public trust and support. It is also

mistakes, conceding the question of whether diversity in fact constituted a compelling constitutional interest. See Complaint for Declaratory, Injunctive, and Other Relief at 9 123, Fisher v. Texas, No. A-08-CA-263-SS, (W.D. Tex April 7, 2008) ("To the extent that UT Austin articulates an interest in promoting 'student body diversity,' Plaintiff does not challenge this interest."). The policies at issue have, at least for the time being, been held to be in compliance with the mandates of Grutter and Gratz. See Fisher v. Univ. of Tex. at Austin, No. A-08-CA-263-SS (W.D. Tex Aug. 17, 2009) (order granting summary judgment in favor of all defendants). The organization that brought the suit, the Project for Fair Representation, has, however, "vowed to appeal as far as necessary." Scott Jaschik, Court Win for Affirmative Action, INSIDE HIGHER EDUC., Aug. 19, 2009, available at http://www.insidehighered.com/news/2009/08/18/texas.

367. Hurtado, Linking Diversity, supra note 149, at 189.

368. Id. 
the surest way to discharge higher education's most fundamental obligation: providing sound educational programs and experiences for the students it serves. 